\title{
SOCIAL MEDIA AS A STORYTELLING LANDSCAPE: ANALYZING CONTENT \& ENGAGEMENT IN PUBLISHER'S SOCIAL MEDIA
}

\author{
by \\ MARTA SOSZYNSKI

\begin{abstract}
A Major Research Paper presented to Ryerson University in partial fulfillment of the requirements for the degree of Master of Digital Media
\end{abstract} \\ in the program of Digital Media \\ Toronto, Ontario, Canada, 2018
}

(C) Marta Soszynski, 2018 


\section{AUTHOR'S DECLARATION FOR THE ELECTRONIC SUBMISSION OF A MRP}

I hereby declare that I am the sole owner of this MRP. This is a true copy of the MRP, including any required final revisions.

I authorize Ryerson University to lend this MRP to other institutions or individuals for the purpose of scholarly research.

I further authorize Ryerson University to reproduce this MTP by photocopying or by other means, in total or in part, at the request of other institutions or individuals for the purpose of scholarly research.

I understand that my MRP may be made electronically available to the public. 


\author{
ABSTRACT \\ SOCIAL MEDIA AS A STORYTELLING LANDSCAPE: \\ ANALYZING CONTENT \& ENGAGEMENT IN PUBLISHER'S SOCIAL MEDIA \\ Marta Soszynski \\ Master of Digital Media \\ Digital Media \\ Ryerson University, 2018
}

Understanding user expectations for using specific SNS platforms may help better manage affordances to fit characteristics of a brand's persona. This paper attempts to gain insight into book publisher's current social media strategies and how affordances are being used to enhance engagement.

A content analysis was conducted on three publishers on their Facebook and Instagram. Posts were categorized according to type. The most engaging post types were identified, and affordances were quantified. Finally, it was determined what engagement dimensionalities were embedded in comments.

Findings indicated that all publishers maintained similar post content between the two platforms, of a product-type. Dialogue-type content was the most engaging. Affective and behavioral dimensions were found in comments made by consumers, and cognitive engagement was primarily found in administrator replies.

Findings provide additional insight on social media affordance use by brands, the relevance of engagement dimensions, and the relationship between brands and online communities. 


\section{ACKNOWLEDGEMENTS}

The conception and completion of this MRP would not have been close to possible without the help, time, energy and support of numerous individuals academically and beyond.

Above all, I'd first and foremost like to thank Dr. Laila Rohani for her supervision over this MRP the past few months. I thank you for your dedication, time and effort into helping me shape this paper and research into the best it can possibly be. I am beyond grateful for all your patience with me this past year, and your academic advice and wisdom. Thank you to Dr. Anthony Francescucci for agreeing to second-read this paper, and for your time, energy and edits into fine-tuning this paper to its best.

I'd like to also thank Kate McKenzie and the Transmedia Zone for the inspiration and advice that drove the very beginnings of this paper. Your words of encouragement and advice were more than enough to drive me in the right direction and build up confidence in my own abilities at times when I had none.

Thank you to all members of the Faculty at Ryerson University - particularly to my instructors this past year - Dr. Alevtina Naumova, Dr. Richard Lachman, and Dr. Sean Wise: your expertise and advice have all been crucial in developing the foundations of what I wanted to achieve with this research, and allowed me to build my skills and abilities to their fullest potential.

Moreover, a big thank you to all my MDM 5.0 classmates. The laughter and experiences we shared this past year helped keep me grounded and sane during this whole process. Your friendship, endless support and advice with all my endeavours have been inspiring and kept me hopeful and confident in my ideas. I am beyond lucky to have spent a year with you all.

And finally, a thank you to my family - my mother, Aneta and my sisters Ania and Ola. Thank you for your love and support, and listening ears when I needed them. Above all, thank you for patiently managing my stress as I wrote this paper, keeping me fed and sane. Nothing would not have been possible without you.

Thank you. 


\section{TABLE OF CONTENTS}

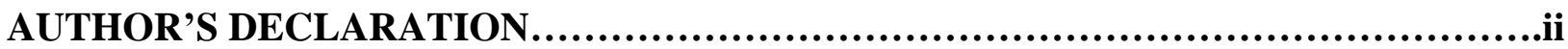

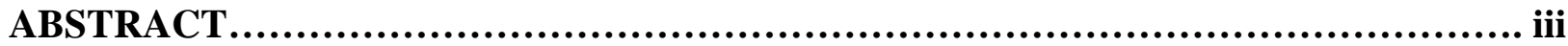

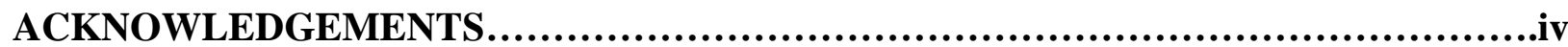

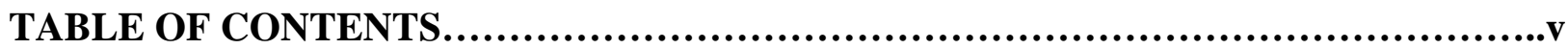

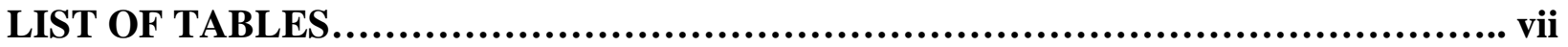

LIST OF FIGURES.......................................................................... viii

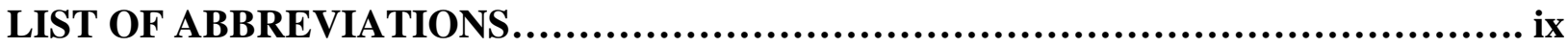

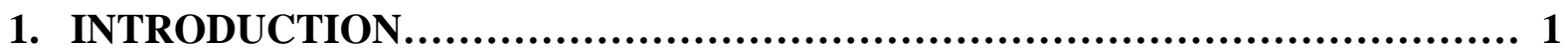

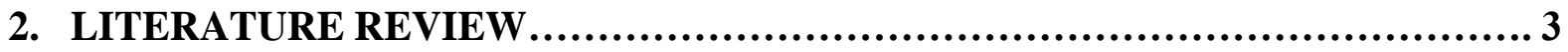

Brand Personas and Engagement 3

Dimensions and Subdimensions of Consumer Engagement 4

$\begin{array}{lr}\text { Social Media Affordances } & 6\end{array}$

$\begin{array}{lr}\text { Storytelling } & 8\end{array}$

3. RESEARCH QUESTIONS......................................................... 10

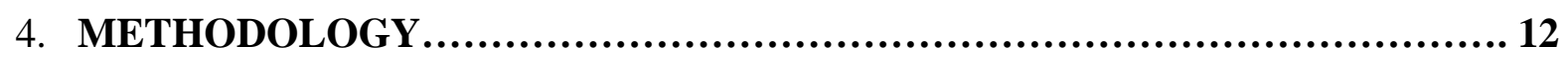

$\begin{array}{ll}\text { The Publisher Brands } & 12\end{array}$

$\begin{array}{ll}\text { Quantifying Engagement } & 14\end{array}$

$\begin{array}{ll}\text { Determining Post Type } & 15\end{array}$

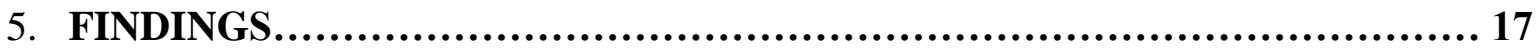

The Emphasis of Product-Type Posts by Publishers

and Engagement in Dialogue-Type Posts by Consumers 19

The Use of Comments on Facebook and Likes on Instagram 22 
6. DISCUSSION ....................................................................... 33

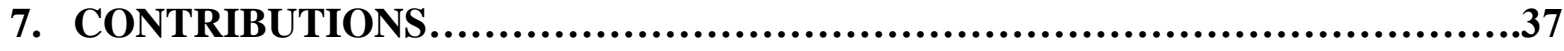

8. FUTURE RESEARCH..............................................................39

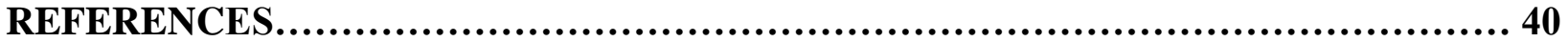




\section{LIST OF TABLES}

TABLE 1.

List of Publishers and Respective Social Media

Accounts Used for Content Analysis.................................................. 13

TABLE 2.

Total Number of Posts Made for Each Publisher...................................... 17

TABLE 3.1.

Percentages of Post Types Evident on Facebook......................................... 19

TABLE 3.2.

Percentages of Post Types Evident on Instagram.................................... 19

TABLE 4.1.

Total \% of Affordances Used / Engagement for

Each Post Type - Facebook.......................................................... 21

TABLE 4.2.

Total \% of Affordances Used / Engagement for

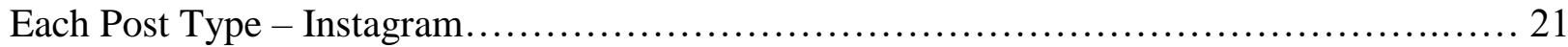

TABLE 5.1.

Engagement Dimensions Evident in Facebook

Comments for Each Publisher....................................................... 31

TABLE 5.2.

Engagement Dimensions Evident in Instagram

Comments for Each Publisher....................................................... 32 


\section{LIST OF FIGURES}

\section{Figure 1.1.}

Number of Facebook Posts Made Per Week

Between All Three Publishers.......................................................... 18

\section{Figure 1.2.}

Number of Instagram Posts Made Per Week

Between All Three Publishers............................................................ 18

Figure 2.1.

Engagement by Affordance Use for Each Post Type

on Facebook.......................................................................... 20

\section{Figure 2.2.}

Engagement by Affordance Use for Each Post Type

on Instagram.

Figure 3.1.

Use of Affordances Between all Publishers

on Facebook

Figure 3.2.

Use of Affordances Between all Publishers

on Instagram.

\section{Figure 4.1.}

Total Number of Likes Used Between Platforms

Figure 4.2.

Total Number of Comments Used Between Platforms 


\section{LIST OF ABBREVIATIONS}

$\begin{array}{ll}\text { CBE } & \text { Consumer-Brand Engagement } \\ \text { HC } & \text { Harper Collins Canada } \\ \text { PRHC } & \text { Penguin Random House Canada } \\ \text { RQ1 } & \text { Research Question 1 } \\ \text { RQ2 } & \text { Research Question 2 } \\ \text { RQ3 } & \text { Research Question 3 } \\ \text { SNS } & \text { Social Network Site(s) } \\ \text { SS } & \text { Simon \& Schuster Canada }\end{array}$




\section{INTRODUCTION}

Print and e-book publishers have been struggling to maintain consumer interest with the rising popularity of independent book stores, combined with trying to keep up with constantly-developing digital technologies. With a current revenue of two billion dollars, the Canadian publishing market is experiencing a $4.5 \%$ decline in growth in the past five years (IBIS, 2018). Publishers relied on e-books to increase revenue (IBIS, 2018), however, though e-books were expected to be extremely popular with readers, both ebooks and print book sales have continued to drop (Nawotka, 2017; BookNet Canada, 2018; Anderson, 2017). As with other brands and corporations, publishers have turned to social media platforms to expand and maintain their brand personas and build meaningful relationships with their consumer base, and, as a whole, increase engagement. Social media platforms have become increasingly intertwined in the lives of everyday consumers, making these platforms ideal for regular communication between brands and consumers.

The participatory and customizable nature of social media platforms makes them ideal for storytelling experiences (De Fina, 2016), an ideal for social media marketing strategies. Each social media platform a brand controls needs to contribute a single, self contained part of a brand's personality or story to the consumer (Cronin, 2015). It is crucial to understand how a social media platform is designed and how its affordances fulfill consumer motivations and expectations when using that particular platform. This way, brands may correctly manage a platform's affordances to fit their brand persona and tell a specific part of the brand's story. This research attempts to gain insight on publisher's current social media, their use of affordances and how publishers are currently engaging with their consumers. This will help determine the effectiveness of consumer engagement through use of different affordances and between differing social media platforms.

Little to no research has been completed on the brand personas and brand engagement of book publishers and their consumer base - thus the analyses made in this paper will allow for a better understanding on the book publishing market in a social media context. Publishers may obtain a better understanding of their consumers, what consumers expect from publisher brands 
online, and how this market engages with a brand on social media platforms. Though online engagement does not directly correlate or guarantee an increase in product sales (or book sales in this instant), it is hypothesized that by making analyses in how books are portrayed and advertised in social media contexts and consumers' responses to these posts, may provide a better grasp on how books may be effectively marketed in digital media environments. This will allow publishers the opportunity to grow and implement better digital media marketing strategies, reflective of their brand persona, through the examples of the publishers researched here. 


\section{LITERATURE REVIEW}

\section{BRAND PERSONAS AND ENGAGEMENT}

The concept of brand engagement has been repeatedly emphasized as an important component in engagement and trust relationships between brands and consumers. Brands are being encouraged to act as a persona - an extension of the brand's personality which acts as a trustworthy and memorable counterpart to a consumer (Herskovitz and Crystal, 2010; Fournier, 1998). Brand's personas are also encouraged to be simplified and fall into a mold of a recognizable archetype which consumers can more easily relate to (Herskovitz and Crystal, 2010, \& Papadatos, 2006). Building a closer relationship between brands and consumers through engagement shifts the role of the consumer from passive to an active one, as they take on a role of being a "co-creator" that builds alongside brands. Consumers are no longer content with being "bystanders (Hanna, Rohm \& Crittenden, 2011)"; thus, brands are encouraged to innovate tools and strategies that always include consumers to take up a more participatory role in the brand experience (Gambetti \& Graffigna, 2010, Berthon et al., 2007).

Engagement has been characterized as a motivational and multidimensional state comprised of several cognitive, behavioral and emotional dimensions, with varying levels of intensity (Brodie et al. 2013; Hollebeek, Glynn, \& Brodie, 2014; Dessart, Veloutsou, \& Morgan-Thomas, 2015). Engagement as a whole has been coined differently throughout research, from "consumer engagement", "brand engagement" and "customer engagement" (Dessart, Veloutsou, \& Morgan-Thomas, 2015). Research in engagement, particularly in the area of online engagement, continues to evolve and develop with changes in digital technology, especially on social media platforms. Consumer-Brand Engagement (CBE), for example, has been coined to cover more interactive components of engagement covered in social media and online environments. CBE also relies more on the consumer's self, or personal, connection to the brand itself rather than just being involved with the brand (Hollebeek, Glynn \& Brodie, 2014). CBE has also focused on information exchange between consumers on social media 
rather than information delivery - again, focusing on relationships (Shen \& Bissell 2013).

Research in engagement on social media remains speculative. Gaining insight into how current engagement theories are being realized and potentially integrated into the real-world may help support past research or help guide future research in this area.

\section{DIMENSIONS AND SUBDIMENSIONS OF CONSUMER ENGAGEMENT}

Throughout research, CBE on social media has been acknowledged as having multiple dimensions, or categorizations by researchers (Dessart, Veloutsou, \& Morgan-Thomas, 2015). CBE has been subcategorized into several different aspects of behavior. Two "engagement objects" have been identified by research: consumers participating alongside one another in the online community, and with the brand itself, represented by the corporate brand representative, or "administrator" (Dessart, Veloutsou, \& Morgan-Thomas, 2015, p.33). Researchers have claimed that dimensions of CBE have been shown to be exhibited by these two engagement objects, though emphasis of past research have been on consumer behavior. CBE has shown in previous research to be multi-dimensional, and recently has thus been presented by Dessart, Veloutsou, \& Morgan-Thomas (2015) into a comprehensible framework with categories (affective, cognitive and behavioral engagement) and respective subcategories (enthusiasm, enjoyment, attention, absorption, sharing, learning and endorsing).

\section{Affective Engagement}

Affective engagement is defined by Dessart, Veloutsou, \& Morgan-Thomas (2015), as "[capturing] the summative and enduring levels of emotions experienced by a consumer with respect to his/her engagement focus... [transpiring] through long-lasting and recurring feelings, rather than one-off emotions (p.35)". Sub-categories of affective engagement include enthusiasm and enjoyment. Enthusiasm is characterized by consumer's levels of excitement and interest with the brand, maintained by interactions, whereas enjoyment is found within those interactions between the consumer and brand/brand community itself (Dessart, 
Veloutsou, \& Morgan-Thomas, 2015). Consumers exhibiting affective engagement sustain engagement by continuing to interact with the brand and the community when they see that others are responding to them and when they recieve notifications that others are commenting on their posts (Dessart, Veloutsou, \& Morgan-Thomas, 2015, p.35).

\section{Cognitive Engagement}

Cognitive engagement is defined as an "enduring and active mental status that a consumer experiences... with a difficulty to detach [oneself] from social media platforms, once connected...due to interesting and entertaining content posted by brands (Dessart, Veloutsou, \& Morgan-Thomas, 2015, p.36)". This engagement type is characterized by attention and absorption, and examples include giveaways and contests where consumers are "glued" to a brand's social media and spending their time directly engaging with it. Consumer's engagement is triggered and sustained by other community members and the brand's activities online as well. Attention is relevant when users are self aware and voluntarily interacting with the brand and are "present" in its community. Absorption, in comparison, is more unconscious, where a brand's interesting content and postings keep users attached to their social media outside the user's self control (Dessart, Veloutsou, \& Morgan-Thomas, 2015).

\section{Behavioral Engagement}

Behavioral engagement is conceptualized by researchers as a consumer's "manifestation toward a brand...beyond purchase...[resulting] from motivational drivers (Dessart, Veloutsou, \& Morgan-Thomas, 2015)". It is defined by sharing where consumers are actively providing and exchange information - personal or informational - and are "driven by the motivation to provide resources [for other consumers] (Dessart, Veloutsou, \& Morgan-Thomas, 2015)"; learning, where consumers engage by asking the brand or other consumers for resources or information (Hennig-Thurau et al., 2004), allowing consumers to have their questions answered freely (Dessart, Veloutsou, \& Morgan-Thomas, 2015); and by endorsing, where engagement goes beyond the online community, exhibited by social media affordances like "liking" a page or post, where consumers "actively recommend specific brands, 
products/services, organizations and/or other ways of using products or brands (Brodie et al., 2013)".

These categories and sub-categories characterize online engagement practices directly exhibited by consumers in Dessart, Veloutsou, \& Morgan-Thomas's 2015 study. Little has been done to determine how these categories and subcategories of engagement affect brand activity on social media and consumer's use of affordances. Additionally, research has yet to determine whether these categories can also be inhibited directly by the brand's administrator online, outside the consumer, and if these categories and subcategories are directly reflected in social media affordances and, finally, if they can be correlated directly with a specific social media website.

\section{SOCIAL MEDIA AFFORDANCES}

The shifting role of consumers and the necessity for brands to build on an environment that includes consumers fits well with what social media platforms in Web 2.0 provide - "the creation and exchange of user-generated content (Kaplan \& Haenlein, 2010, p.1)". Social media platforms not only provide an ideal storytelling environment between consumers and brands their affordances also help contribute to the same self meaning-making that motivates people, in general, to engage in storytelling thinking.

Social media platforms provide users with a high degree of both, social presence and self presentation. Social media is defined as "internet-based applications that build on the ideological and technological foundations of Web 2.0...focused on the creation and exchange of user-generated content (Kaplan \& Haenlein, 2010, p.1)”. Thus, social media platforms provide users with several affordances or functions that fulfill this content exchange between users (like liking, linking and editing) (Cabiddu et al., 2014), contributing to communication and allowing for a great deal of user control (Livingstone, 2008). Allowing users such control in its affordances, social media fulfills several self identity needs for users. Studies have found 
consistent reasons for people regularly using social media platforms - from communication and interaction between friends (Whiting, 2013), to finding and sharing information (O'Riordan, Feller, \& Nagle, 2012), notably, with different degrees of engagement from individualized users (Brandtzaeg, 2011).

Different affordances on social media fulfill the needs users expect when they log into a social media platform, particularly a Social Networking Site (SNS). According to Kaplan \& Haenlein (2010), social media provides users varying degrees of social presence (the degree to which two individuals are able to communicate) and self-presentation (the degree to which an individual can control the impressions others have of him/her, driven by rewards and/or a need to create an image consistent with his/her personal identity). In general, SNS provide similar features in "different contexts" that fulfill needs of social presence and self-presentation (O’Riordan, Feller \& Nagle, 2012). These features include, for example, hashtags (which help users easily find and share content between friends), profile customizability and photo editing (allowing users to manipulate individual context and meaning to the posts they share (Weilenmann, Hillman \& Jungselius, 2013)), and tagging (which encourage interconnectivity between friends and preserve a sense of self presentation) (Hussein, Alaa, \& Hamad, 2011). Because of these affordances, social media is being classified by researchers as "consumer-generated media", making the platforms ideal for marketing and promotions (Mangold \& Faulds, 2009).

Research has also previously suggested that consumers prefer certain social media platforms over others, because of the individual platform's differing networking opportunities. For example, Facebook facilitates more self-expression and Instagram/Twitter are used more as "personal branding tool[s] (Dessart, Veloutsou, \& Morgan-Thomas, 2015)". However, overwhelmingly, it was found that consumers favour social media platforms as means to directly interact with brands (Kaplan and Haenlein, 2010), favouring their informational value and the ability to directly interact with favoured brands, and network with other consumers (Dessart, Veloutsou, \& Morgan-Thomas, 2015). Little research is evident as to how consumers use social media affordances to reflect these desires. 


\section{STORYTELLING}

Since its beginnings in oral traditions, the process of storytelling has been vital in contributing and making sense of the human experience. The human brain is said to be "wired for story telling", standing as a key component in everyday meaning-making, education, and understanding of the world and oneself (Mar, R.A., 2004 \& Gottschall, 2012). This causes people to think more "narratively, rather than argumentatively or paradigmatically (Woodside, Sood \& Miller, 2008)". The relationship between tellers and listeners of a story is emphasized as being extremely important - allowing an individual listener to draw personalized conclusions of him/herself. Stories help contribute to the way that a person thinks about his/her "self" - and though stories may be told by the teller in the same way, the conclusions that listeners take from a story are always different (Nelson, 1989, Randall et al., 2006).

Storytelling is a powerful concept. It has played, and continues to play, a vital part in the relationship between brands and consumers. The role of storytelling and the ideal of creating a brand persona has been repeatedly emphasized in consumer-brand relationship research. Stories have been found to be key in persuading consumers to action (Woodside, Sood \& Miller, 2008), especially those involving archetypes, allowing consumers to relate with brands on a more emotional level (Papadatos, 2006). Because of this, storytelling has been evidenced in social media marketing strategies due to the participatory and customizable nature of social media platforms that make them ideal for collaborative storytelling experiences (De Fina, 2016).

This paper attempts to clarify and evidence these theoretical conceptualizations of consumer engagement dimensions, consumer affordance use and storytelling on social media platforms through practical, real-world implications and longitudinal analysis. It attempts to fill

in the gaps and create a hybrid of findings that takes all these concepts into account, unlike past research has done.

Past literature fails to realize how social media affordance use is indicative of engagement and if these engagement dimensions can be realized in real-world circumstances. 
Dimensions of engagement - affective, cognitive and behavioral - have been shown to be exhibited by consumers (Dessart, Veloutsou, \& Morgan-Thomas, 2015). However, they have yet to be evidenced by online brand administrators, their online interactions and through affordance use by consumers and administrators, alone. Additionally, social media affordances have not shown to correlate with particular engagement dimension(s). Determining if engagement dimensions are realized in affordance use and how they are attributed to specific affordances and SNS platforms could help evolve conceptualizations of online engagement in future research.

Moreover, past literature indicates social media affordances as fulfilling consumer's motivations and expectations of using a particular SNS platform (Kaplan \& Haenlein, 2010; O'Riordan, Feller, \& Nagle, 2012). However, it has yet to show how specific SNS affordances demonstrate engagement dimensions defined by Dessart, Veloutsou \& Morgan-Thomas, 2015. Redefining consumer's affordance use in the context of engagement could help to continue to evolve research in both these areas.

SNS affordances allow for communication and interaction between consumers and brands. Thus, social media appeals to a consumer's new active role of "co-creator". Past literature does not go into detail as to how specific affordance and SNS platform use can represent different facets of a brand's personality to build a brand storytelling experience (Scolari, 2009). Observing how a consumer's role of "co-creator" is seen in brand-consumer interactions online and how affordances are used on specific platforms can realize how a brand's story and personality is conceptualized and effectively demonstrated in social media. 


\section{RESEARCH QUESTIONS}

The overarching objective of this research is to gather a better perspective and understanding of how publishers are currently personifying their brand personas on Facebook and Instagram, and how they're engaging with their consumer base in a social media context. By measuring current levels of engagement on social media platforms, the effectiveness of specific affordances in enhancing engagement between publishers and users can be determined. Findings may also determine whether specific affordance use may deter or effectively increase more meaningful engagement between publishing houses and their consumers. These objectives can be defined in the following three research questions.

Firstly, according to Shen and K. Bissell (2013), in order to determine the effectiveness of good brand marketing, it is important to note which social media posts are the most engaging and "viral" for consumers, allowing the post to spread exponentially on SNS to friends of consumers on platforms like Facebook. Additionally, analyzing post types on each platform will help define the publisher brand persona and how it is exhibited differently, or similarly, on different SNS platforms. Observing what types of posts consumers are currently engaging with, and understanding how a post's content engages or disengages consumers in the context of a specific SNS platform can be indicative whether future posts can be manipulated to fit the context of a specific SNS platform or affordance.

\section{RQ1 - What are the most engaging post types on Facebook and Instagram pages for the three book publisher brands, Penguin Random House, Harper Collins and Simon \& Schuster? How do these posts engage their consumers on Facebook and Instagram?}

Noting what types of posts publishers are posting on social media, and understanding which are most effective for consumer engagement may then, secondly, provide an understanding as to how publishers are asking consumers, (directly or indirectly) to engage with these posts. Observing how publishers ask consumers to engage, and whether affordance use 
differs between platforms may contribute to an understanding of why and how consumers use specific affordances on specific platforms.

\section{RQ2 - How do the three book publisher brands use affordances (like, share and comment) on their Facebook and Instagram pages respectively to engage consumers? How does the use of affordances differ between platforms?}

Thirdly, levels and effectiveness of brand-consumer engagement need to be defined as they currently exist, or are absent on publisher's social media. According to Dessart, Veloutsou

$\&$ Morgan-Thomas (2015), three types of engagement (affective, cognitive and behavioral) have shown to be relevant and direct in consumer's online interactions with brands on social media. By determining the presence or absence of these engagement dimensions, the context of the social media platform and its respective affordances in implementing these dimensions can be discussed. Additionally, it can be examined what role specific affordance use plays into initiating specific engagement dimensions.

RQ3- What dimensionality of engagement is embedded in the three book publisher brands' online brand communities? 


\section{METHODOLOGY}

The primary approach was a content analysis. Content Analyses “interpret meaning from the content of text data... [involving] counting and comparisons, usually of keywords and content, followed by [an] interpretation of the underlying context (Hsieh H.F. and Shannon, S.E., 2005)". A content analysis will allow for detailed insight into how consumers are interacting with publishers on social media and the types of engagement these comments exhibit. This will also allow findings to zero in into user's online interactions, detailing what consumers and the publisher's online administrator are talking about with one another and how they're using affordances to reflect and encourage these interactions. These insights may provide additional insights into to the publisher's specific consumer-base.

\section{THE PUBLISHER BRANDS}

First, an understanding of publisher's brand, as personified on social media, needed to be defined. This was done by examining the content posted by three independent publishing houses - Penguin Random House Canada (PRHC), HarperCollins Publishers (HC), Simon \& Schuster (SS) - on their respective Canadian Facebook and Instagram accounts. These publishers are a part of the "Big Five" publishing houses in the world, producing 60\% of all English-language books in the U.S. alone (Losowsky A., 2013). These publishing houses all operate on a global level with a division and office dedicated to the Canadian market. These houses also have an official Facebook and Instagram account based on their Canadian division. Thus, choosing to examine the content of these houses' Canadian accounts allows the research to cater specifically to the relationship between the publisher and the Canadian consumer-base. Details of each Publisher's social media accounts are listed in Table 1.

\section{Penguin Random House Canada (PRHC)}

PRHC is the Canadian division of Penguin Random House, considering itself to be the "largest global trade book publisher" (PRHC, 2018). With headquarters based in New York City, Penguin Random House was formed on July 1, 2013 as a merger between Random House 
(founded in 1927, and currently owning 53\% of the venture) and Penguin Group (founded in 1935, and currently owning $47 \%$ of the venture), handling adult/children's fiction/non-fiction print and digital trade book publishing, with operations in 20 countries, including Canada. Across 250 independent imprints and publishing houses, Penguin Random House collectively publishes over 15,000 print titles and 70,000 digital titles annually (PRHC, 2018). The PRHC brand prides itself in "[fostering] a universal passion for reading by partnering with authors to help create stories and communicating ideas that inform, entertain, and inspire, and to connect them with readers everywhere (PRH, 2018)".

TABLE 1. List of Publishers and Respective Social Media Accounts Used for Content Analysis.

\begin{tabular}{|c|c|c|c|c|c|c|}
\hline Publisher & $\begin{array}{c}\text { Canadian } \\
\text { Office }\end{array}$ & Website & $\begin{array}{l}\text { Facebook } \\
\text { Page Link }\end{array}$ & $\begin{array}{c}\text { Facebook } \\
\text { Page } \\
\text { Followers }\end{array}$ & $\begin{array}{l}\text { Instagram } \\
\text { Page Link }\end{array}$ & $\begin{array}{c}\text { Instagram } \\
\text { Page } \\
\text { Followers }\end{array}$ \\
\hline $\begin{array}{c}\text { Penguin } \\
\text { Random } \\
\text { House } \\
\text { Canada }\end{array}$ & $\begin{array}{l}320 \text { Front St } \\
\text { W \#1400, } \\
\text { Toronto, ON }\end{array}$ & $\begin{array}{l}\text { https://pengui } \\
\text { nrandomhous } \\
\text { e.ca/ }\end{array}$ & $\begin{array}{l}\text { https://www.f } \\
\text { acebook.com } \\
\text { /PenguinRan } \\
\text { domCA/ }\end{array}$ & 59,216 & $\begin{array}{l}@ \text { penguinran } \\
\text { domca }\end{array}$ & 24,481 \\
\hline $\begin{array}{l}\text { Harper } \\
\text { Collins } \\
\text { Canada }\end{array}$ & $\begin{array}{l}22 \text { Adelaide } \\
\text { St, Toronto, } \\
\text { ON }\end{array}$ & $\begin{array}{l}\text { https://www. } \\
\text { harpercollins. } \\
\text { ca/ }\end{array}$ & $\begin{array}{l}\text { https://www.f } \\
\text { acebook.com } \\
\text { /HarperColli } \\
\text { nsCanada/ }\end{array}$ & 137,077 & $\begin{array}{l}\text { @harpercolli } \\
\text { nsca }\end{array}$ & 23,969 \\
\hline $\begin{array}{l}\text { Simon \& } \\
\text { Schuster } \\
\text { Canada }\end{array}$ & $\begin{array}{l}166 \text { King St } \\
\text { E, Toronto, } \\
\text { ON }\end{array}$ & $\begin{array}{l}\text { http://www.si } \\
\text { monandschus } \\
\text { ter.ca/ }\end{array}$ & $\begin{array}{l}\text { https://www.f } \\
\text { acebook.com } \\
\text { /SimonSchus } \\
\text { terCA/ }\end{array}$ & 21,931 & $\begin{array}{l}@ \text { simonschu } \\
\text { sterca }\end{array}$ & 11,747 \\
\hline
\end{tabular}

\section{HarperCollins Publishers (HC)}

Founded in 1817, HarperCollins Publishers is headquartered in New York City, with operations in 18 countries, including Canada, making it the "second-largest consumer book publisher in the world (HarperCollins, 2018)". HarperCollins covers several genres of books, 
publishing about 10,000 titles every year in more than 120 different imprints, in 17 different languages. The Harper Collins brand promises to keep "authors and their work...at the center of everything [HarperCollins] does", gifting their authors with talented editors, marketing reach and network connections as well as insights into consumer and reader behavior (HarperCollins, 2018).

\section{Simon \& Schuster Publishing (SS)}

Founded in 1924, and based in New York City, Simon \& Schuster publishes approximately 2,000 titles annually under 35 different imprints (Publisher Weekly, 2016). With a division set in Canada, Simon \& Schuster published "authors who have a purpose, a story to tell, and an unusual talent for making readers care about it".

All three publishing houses have official social media accounts on Facebook and Instagram that were used in this research under the following links and handles listed in Table 1. Analyzing the publishing house's content on both Facebook and Instagram allows the research to cover several different demographics of consumers (with younger users tending to use Instagram, and older users more common on Facebook (Brandtzaeg, 2011).). This, thus, allows the data collected to be representative of a wider spectrum of consumers, all from the same market.

\section{QUANTIFYING ENGAGEMENT}

The first part of the research was completed by quantifying engagement in specific posts made by the publisher over a period of 18 weeks. Engagement in this first part was coded to specific affordances made available to users on every post a publisher posted online. The number of likes, comments (Instagram) and shares (Facebook) were counted from every post made by each publisher between January 1, 2018 and April 30, 2018. Likes, comments and shares are affordances indicative of lower levels of engagement with consumers. Because likes, comments, and shares may differ significantly day to day with unforeseeable factors like users deleting 
accounts, and other users seeing posts later than the day the publisher originally posted, a final quantification was made on May 1, 2018, disregarding any changes in numbers onward.

Because of this, there may be changes to the number of affordances clicked by users following this date. Likes, comments and shares were counted by opening each post up individually in a web browser and reading the number of each displayed at the top of the post. Each counted number was then inputted into an excel sheet individualized for each publishing house.

\section{DETERMINING POST TYPE}

Secondly, publisher's posts were coded and quantified in terms of "Post Type". This was made on the basis of observation. Post Types were coded following a similar coding system made by Shen \& Bissell (2013): Event, Product, Promotion and Dialogue. Posts were coded on the basis of their characteristics. Analyzing language used (primarily on Facebook), comments, descriptions and imagery added to the post by the publisher (primarily on Instagram), and looking at what else was linked along with the post (images, articles, web pages, etc.) were the main factors in determining what category a post should be. Many posts fit into more than one category of coding, however, the most prominent feature of the post was used to tag each post into respective categories. The basis for coding stemmed from determining what a user would first see and prompted to do upon seeing the post for the first time.

Event posts referred to posts that were related to an event occuring in the present or future, made in the form of an announcement. Events were either directly related to the publisher and its employees (a company event, party, CEO announcement, panel, etc.) or indirectly, marketing for a specific title(s) (an author panel, a book signing, a book launch, etc.) or an outside event or holiday more relevant to consumers (Mother's Day, Valentine's Day, a tragic accident).

Product posts clearly promoted a specific book title(s). The post may include a summary of the title(s), reviews of the title(s) by relevant individuals or organizations, the title(s) on-sale date and/or price. The post may also prompt the user to engage in the post by stating through "likes" or "comments" if they are interested/have read/want to read the title(s) featured in the 
post. The book(s) endorsed may be connected through genre, or be presented as a stand-alone feature.

Promotion posts "stimulate demand [for] users (Shen \& Bissell, 2013)", prompting users to directly engage with the post. The posts may feature giveaways, contests, discounts or deals rewarding users with free product(s) if they directly engage with the post itself.

Dialogue posts refer to posts which indicate a "call-to-action" directly or indirectly. The language in the post almost immediately tells users to click links attached to the post, or simply "like" the post itself for its content. A "call-to-action" may be less direct, when the post attempts to be "relatable" to the user, posing questions that a user may choose to engage with (for example, "What do you read when it's cold out", “A day isn't complete without a book!”).

Next, a content analysis of affordances, specifically comments, was made, combining comments on posts made by users and each publisher's respective persona, on each social media platform. Comments analyzed were copied on May 1, 2018 onto a word document, disregarding any changes made following this date. Comments were dated according to the post they were in response to, and compiled into a single document, respective to either Facebook or Instagram. [tag] and [emo] indicated when users tagged others as a response and used an emoji in their response, respectively. User's names and profiles were omitted and line breaks were used in identifying speakers in a comment thread.

Lastly, comments were tagged as representing either affective, cognitive, or behavioral engagement, as according to studies completed by Dessart, Veloutsou, \& Morgan-Thomas (2015). Both comments made by users and comments made by the publisher were accounted for. Comments were then, again, divided into separate word documents (with reach word document representing a different category of engagement) according to what type of engagement they demonstrated, by each publisher respectively. Comments were also labelled with what subcategory they best represented. 


\section{FINDINGS}

The Facebook and Instagram pages of the three publishing house brands were observed and analyzed for 18 weeks to quantify all affordances and determine engagement dimensions. These were all combined to make comparative figures and charts between the three publishing house brands, accordingly.

At the end of the 18 week period, SS totaled the highest number of posts with 207 collectively on Facebook and Instagram, with $65 \%$ of posts favouring Facebook. PRHC totaled 82 posts on both Instagram and Facebook - with 73\% more postings made on Instagram. HC totaled 181 posts collectively, with 64\% more postings made on Facebook. (See Table 2) Table 2 describes the total number of posts made on Facebook and Instagram for each of the three publishers. HC averaged 6.5 Facebook and 3.7 Instagram posts per week. PRHC averaged only 1.3 Facebook and 3.3 Instagram posts per week. SS ranked the highest number of Instagram posts with an average of 4.6 per week, and Facebook posts with an average of 7.6 per week. (See Figure 1.1 and 1.2) Figures 1.1 and 1.2 provide a comparative look into how posts were distributed weekly by each of the publishers.

TABLE 2. Total Number of Posts Made for Each Publisher

\begin{tabular}{|c|c|c|}
\hline Publisher & Facebook Number of Posts & Instagram Number of Posts \\
\hline PRHC & 22 & 60 \\
\hline HC & 115 & 66 \\
\hline SS & 135 & 72 \\
\hline
\end{tabular}


Figure 1.1. Number of Facebook Posts Made Per Week Between All Three Publishers

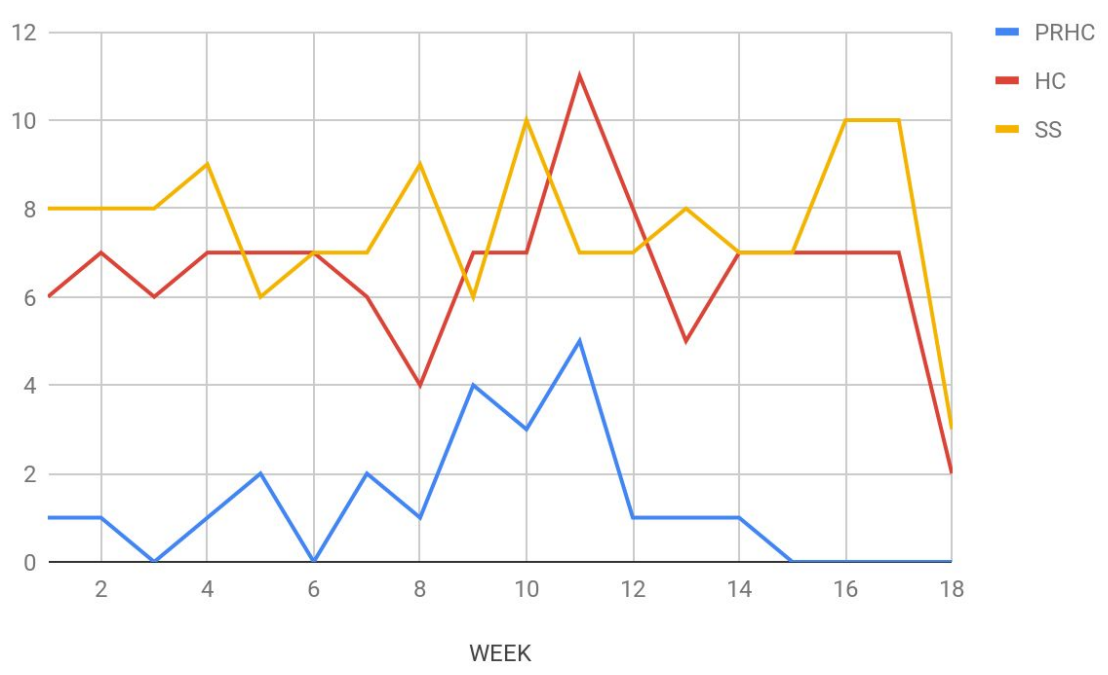

Figure 1.2. Number of Instagram Posts Made Per Week Between All Three Publishers

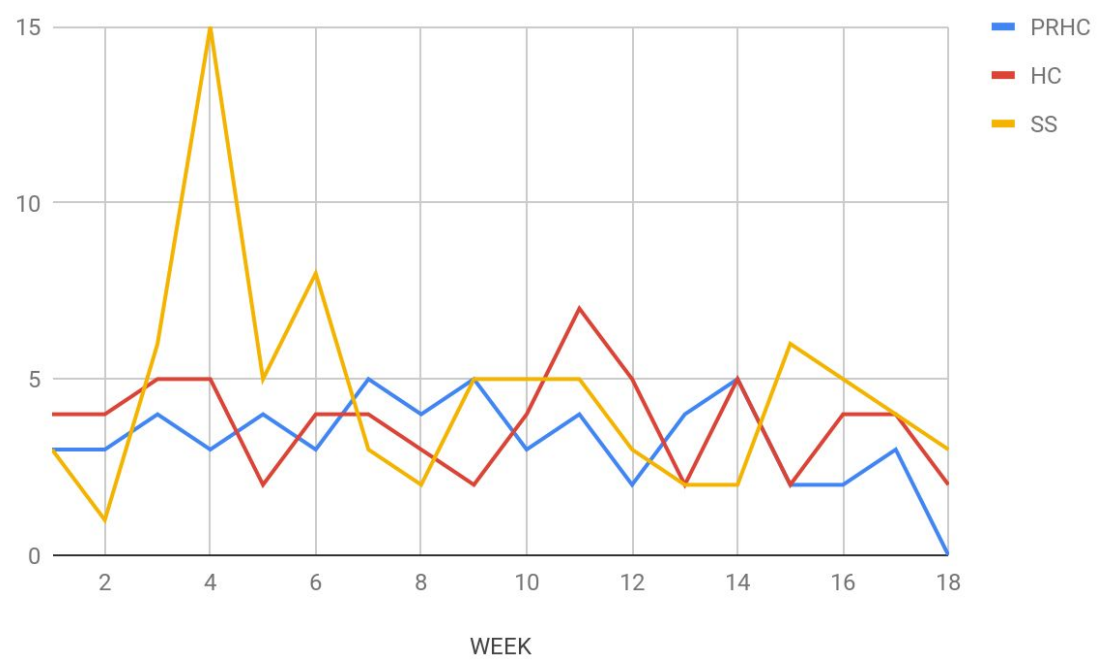




\section{The Emphasis of Product-Type Posts by Publishers \& Engagement in Dialogue-Type Posts by Consumers}

In order to determine the most engaging post-types among the three publishing houses, to answer RQ1, the concept of engagement was determined by the use of affordances (likes, shares and comments) by users on each platform, for each publisher. Due to varying follower counts, and varying number of posts made during the 18 week period, affordances were later converted to stand as percentages out of a hundred, in order to accurately compare affordance use/engagement in the different post types between the three publisher brands.

Generally, all three publishing houses showed a majority of $39 \%$ and higher of posts of a Product type on both platforms (Table 3.1 and Table 3.2). Table 3.1 and 3.2 show the distribution of post types between all three publishers. Event posts were preferred by PRHC on Facebook, unlike the other two houses, with $40.91 \%$ of posts of an event nature.

TABLE 3.1. Percentages of Post Types Evident on Facebook.

\begin{tabular}{|c|c|c|c|c|}
\cline { 2 - 5 } \multicolumn{1}{c|}{} & Event & Product & Promotion & Dialogue \\
\hline PRHC & $40.91 \%$ & $36.36 \%$ & $13.64 \%$ & $9.09 \%$ \\
\hline HC & $19.13 \%$ & $46.96 \%$ & $4.35 \%$ & $29.57 \%$ \\
\hline SS & $23.70 \%$ & $58.52 \%$ & $13.33 \%$ & $2.22 \%$ \\
\hline
\end{tabular}

TABLE 3.2. Percentages of Post Types Evident on Instagram.

\begin{tabular}{|c|c|c|c|c|}
\cline { 2 - 5 } \multicolumn{1}{c|}{} & Event & Product & Promotion & Dialogue \\
\hline PRHC & $16.67 \%$ & $70.00 \%$ & $3.33 \%$ & $10.00 \%$ \\
\hline HC & $30.30 \%$ & $39.39 \%$ & $9.09 \%$ & $31.82 \%$ \\
\hline SS & $5.56 \%$ & $80.56 \%$ & $12.50 \%$ & $1.39 \%$ \\
\hline
\end{tabular}


Figures 2.1 and 2.2 demonstrate how much consumers were engaged with each post type, through how many total affordances were used. As shown in Figures 2.1 and 2.2, engagement was much more equally distributed between all post types, with Product type posts being most engaging for users. Dialogue type posts were more engaging for $\mathrm{HC}$ on both Facebook and Instagram. Product type posts were more engaging on Instagram for users for all publishers. Promotion type posts had a more equal distribution of affordance use/engagement between the two platforms.

Figure 2.1. Engagement by Affordance Use for Each Post Type on Facebook.

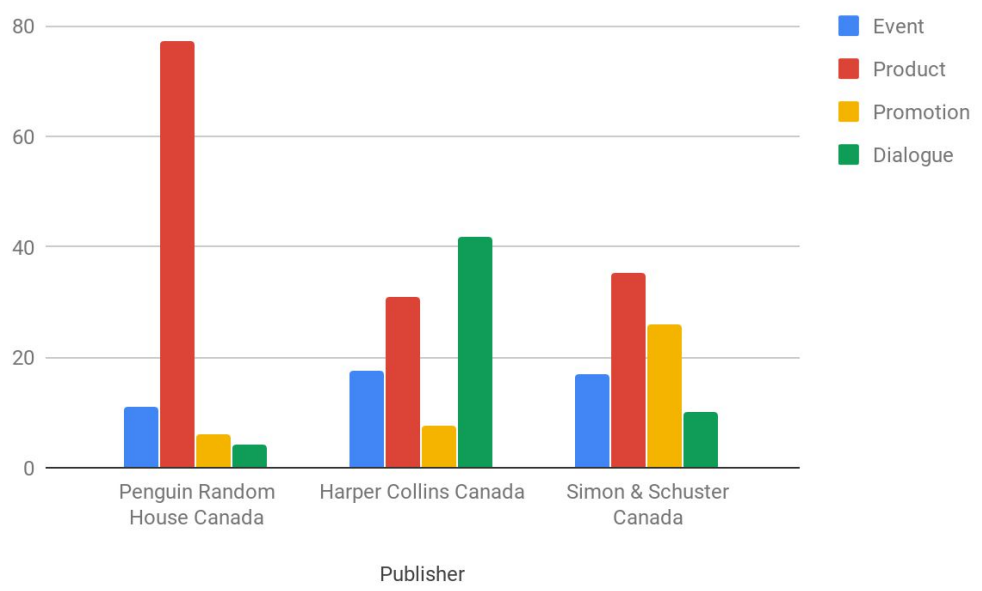

Figure 2.2. Engagement by Affordance Use for Each Post Type on Instagram.

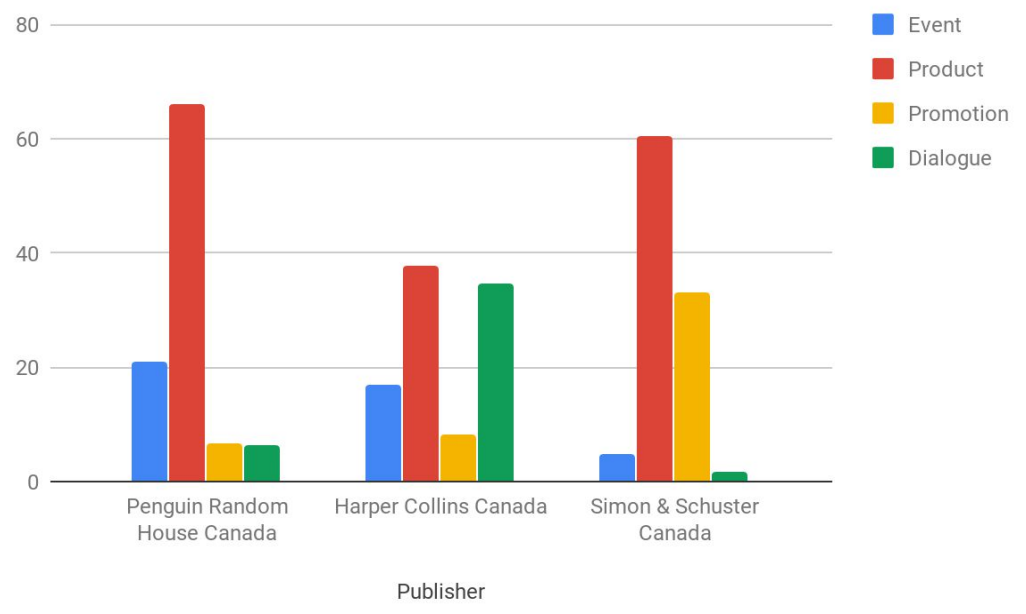


Among both platforms, Promotion type posts had the lowest amount of engagement/affordance use. Detailed below are the percentages of affordances used for each post type, for each respective publishing house (seen in Tables 4.1 and 4.2). Tables 4.1 and 4.2 show the percentage of affordances used for each post type on each platform, with the total number of affordances represented as a whole $100 \%$.

TABLE 4.1. Total \% of Affordances Used / Engagement for Each Post Type on Facebook.

\begin{tabular}{|c|c|c|c|c|c|}
\hline Publisher & Event & Product & Promotion & Dialogue & $\begin{array}{c}\text { Total } \\
\text { Affordances } \\
\mathbf{1 0 0 \%}\end{array}$ \\
\hline PRHC & 11.17 & 77.27 & 6.2 & 4.18 & 3322 \\
\hline HC & 17.52 & 30.85 & 7.68 & 41.7 & 43342 \\
\hline SS & 16.91 & 35.3 & 25.91 & 10 & 1810 \\
\hline
\end{tabular}

TABLE 4.2. \% of Affordances Used / Engagement for Each Post Type on Instagram.

\begin{tabular}{|c|c|c|c|c|c|}
\hline Publisher & Event & Product & Promotion & Dialogue & $\begin{array}{c}\text { Total } \\
\text { Affordances }= \\
\mathbf{1 0 0 \%}\end{array}$ \\
\hline PRHC & 20.98 & 66.15 & 6.6 & 6.27 & 24431 \\
\hline HC & 16.87 & 37.89 & 8.08 & 34.5 & 41636 \\
\hline SS & 4.66 & 60.55 & 33.03 & 1.76 & 12554 \\
\hline
\end{tabular}


The findings for PRHC are as follows. On Facebook, users were most engaged with Product Type posts, accounting for $77.27 \%$ of combined affordance use (likes, comments and shares). The least engaging post type were Dialogue posts with only a total of $4.18 \%$ total use of affordances. On Instagram, like Facebook, users used affordances most with Product Type most, covering $66.15 \%$ of total combined affordance use on the platform. Event Type posts were more engaging for users than on Facebook (9.81\% more engaging), and Dialogue posts were slightly more engaging for users compared to Facebook (2.09\% more engaging).

The findings for $\mathrm{HC}$ are as follows. On Facebook, engagement and affordance use was much more evident in Dialogue posts (41.7\%) and Product posts (30.85\%) alike. Collectively, affordance use on this platform was the highest compared to the other two publisher's pages and Instagram pages, with 43342 combined affordance use. On Instagram, Product (37.89\%) and Dialogue (34.5\%) type posts were the highest in engagement and affordance use by users. Again, this publisher carried the highest number of affordance use compared to the other two. Like Facebook, Promotion type posts were least engaged with (only $8.08 \%$ of all combined affordance use).

For SS, Product type posts were most engaged with (35.3\%) with Promotion type posts being second highest (25.91\%) on Facebook. Dialogue type posts were least engaging for users, collecting only $10 \%$ of all combined affordance use. On Instagram, Product type posts were the highest in engagement/affordance use (60.55\%), with Event and Dialogue posts having the least amount of engagement/affordance use (4.66\% and $1.76 \%$, respectively).

\section{The Use of Comments on Facebook and Likes on Instagram}

To determine how each of the three publishing houses were using affordances, at the end of the 18 week period, affordances (likes, comments, and shares) were calculated for each of the Publishing Houses in order to answer RQ2. Figure 3.1 and 3.2 compare the use of affordances 
between all publishers on each platform. For Facebook, $\mathrm{HC}$ had substantially the highest average of total likes, comments and shares per week - with an average of 1989 likes, 172 comments, and 247 shares per week. This was followed by PRHC having an average of 161 likes, 6 comments and 18 shares per week. SS ranked with the lowest use of affordances, with an average of 81 likes, 7 comments and 12 shares per week. Contrasts between the total number of likes, comments and shares between the three houses can be seen again in Figures 3.1 and 3.2.

Figure 3.1. Use of Affordances Between all Publishers on Facebook.

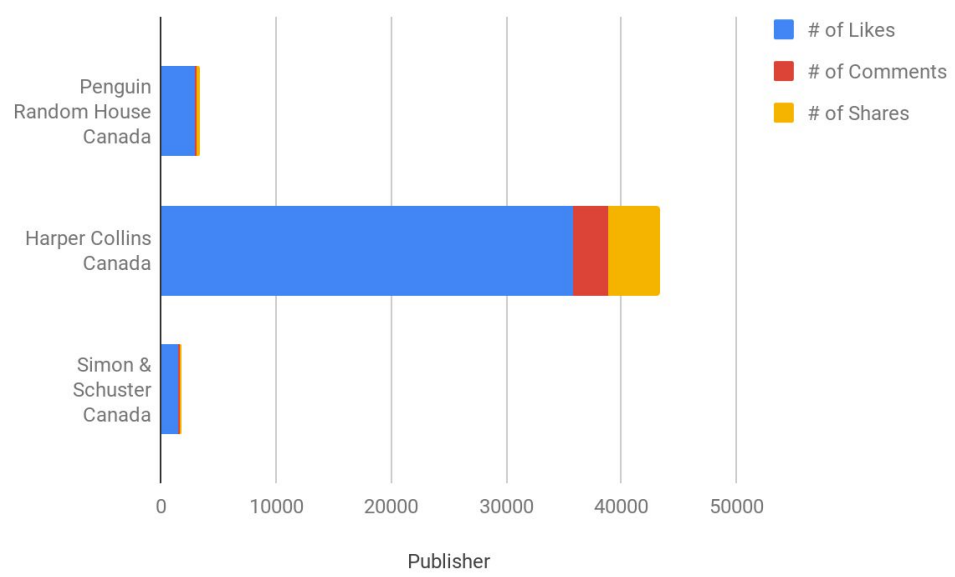

Figure 3.2. Use of Affordances Between all Publishers on Instagram.

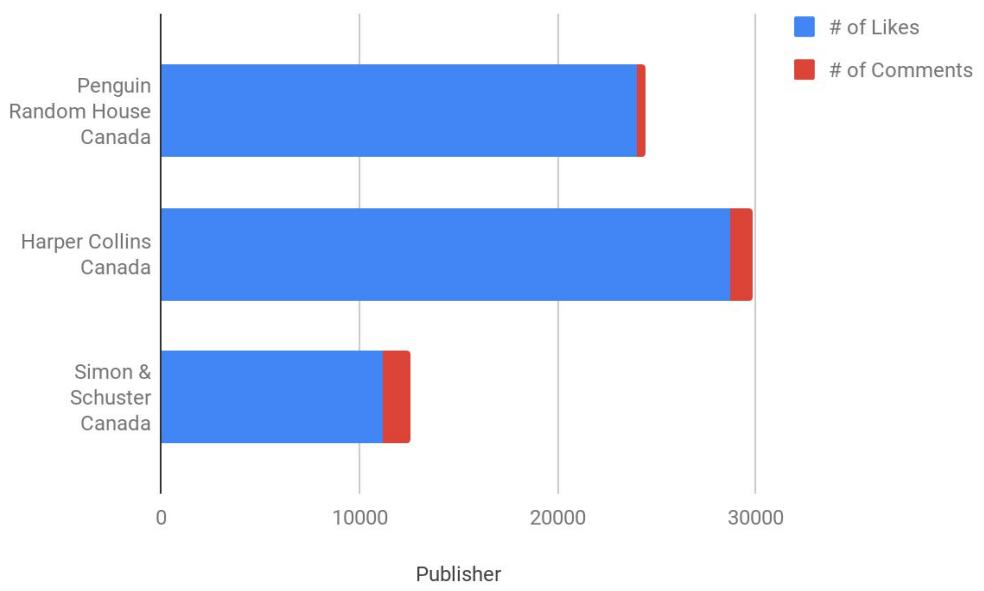


In the case of individualized affordance use, likes were substantially used more by consumers on Facebook and Instagram collectively compared to comments and shares. Share was used more commonly by users than commenting on Facebook. Between the two platforms, likes were used more by users on Instagram, and comments were more utilized on Facebook (as seen in Figures 4.1 and 4.2, demonstrating the use of a single affordance between both platforms). On Instagram, the publishers had more equal distribution of affordance use by consumers. HC carried the highest average amount of likes per week. Comment activity on Instagram differed, with SS averaging the highest number of comments per week and PRHC ranking lowest.

Figure 4.1. Total Number of Likes Used Between Platforms.

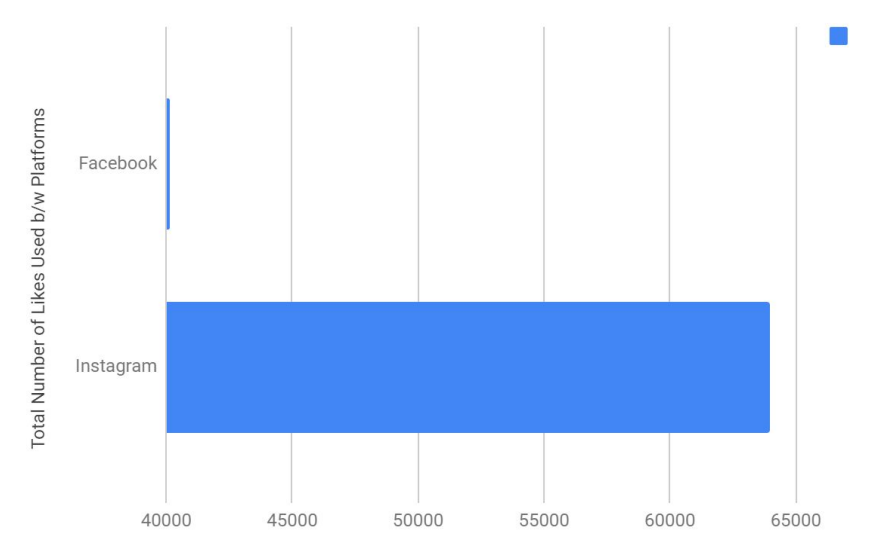

Figure 4.2. Total Number of Comments Used Between Platforms.

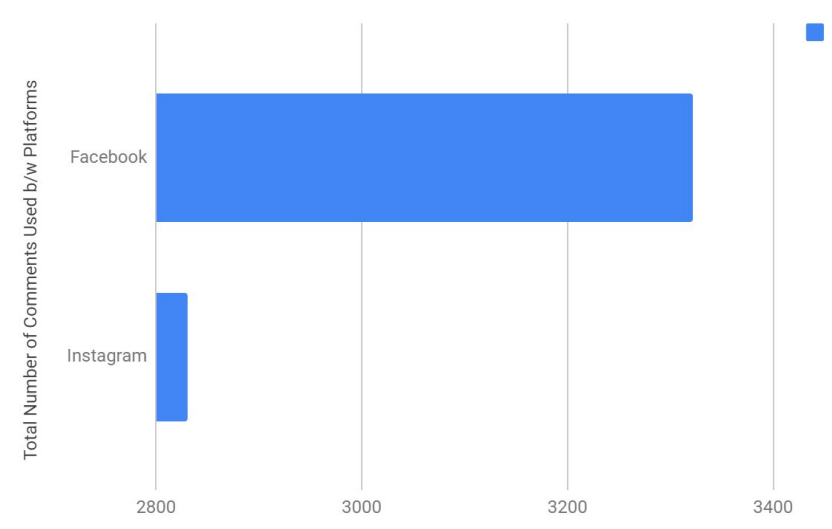




\section{Evidence of Engagement Dimensions in User Comments}

Results found that affective, cognitive and behavioral dimensions suggested by Dessart, Veloutsou, \& Morgan-Thomas (2015) were relevant in comments made by users and through posts made by each publisher. With regards to RQ3, engagement dimensions were identified in each of the publisher's pages on each platform; examples of each dimension are shown in Table 5.1 for Facebook and Table 5.2 for Instagram. Primarily, posts made by the publisher brands on both Facebook and Instagram exhibited cognitive engagement, whereas comments made by users displayed affective and cognitive engagement, and at many times, combined these two types of engagement.

Affective engagement was most commonly found in comments made by users both on Facebook and Instagram. Comments were found exhibiting both enjoyment and enthusiasm from users, written primarily with the same use of language and context. Comments exhibiting enthusiasm, were related to user's excitement (Dessart, Veloutsou, \& Morgan-Thomas, 2015) regarding book covers, new titles, or a giveaway. Examples of such comments include:

User: Love to read...I love reading to my grandkid

$* * *$

User: Ordered your new book today can't wait

$* * *$

User: What a beautiful cover! I have been wanting to read the first book. Would be great to win it!

Enjoyment, "indicative of the consumer's pleasure and happiness derived from interaction from the online brand community (Dessart, Veloutsou, \& Morgan-Thomas, 2015)" was illustrated in comments like: 
User: yes! Those pics show how books make me feel and how they get the gray matter going!

Cognitive engagement was rarely found in comments made by users, and most clearly exhibited by the publisher's administrators and their replies to user's comments and in the posts they made, attempting to foster and maintain engagement among and with users. Posts made by publishers pushed aspects of attention and absorption in their content at users, prompting them to behave in a particular way, and therefore, keeping them online and interacting with others more actively. Posts that exhibited dimensions of attention requires users to be actively present on social media and actively participating with the online community (Dessart, Veloutsou, \& Morgan-Thomas, 2015), and therefore used capitalizations and more directive language as a result. Emojis were used in capturing the user's immediate attention, and administrators also asked users to act with an affordance, for example, asking them to "please like if". Examples of posts that fostered user's attention online include:

\author{
GIVEAWAY ALERT! This Valentine's Day we're turning "Likes" into Love. \\ Like" this post to unlock a giveaway inspired by one of our favourite love stories (soon to be the major \\ motion picture Love, Simon!). \\ 200 Likes unlocks our giveaway. Check back tomorrow to enter to win! \\ $* * *$ \\ The answer is ALWAYS read. \\ "Like" if you agree. \\ Absorption, meanwhile, was more prevalent in the Promotion post-type. Promotion-type \\ posts attempt to keep a user online and engaged with other users (Dessart, Veloutsou, \& \\ Morgan-Thomas, 2015), and was most prevalent in posts promising Giveaways, asking users to \\ tag other users and actively comment to win books and/or other prizes. The success of these \\ Giveaways can be seen by the sudden spikes of affordance use among all publishers. An \\ example of a post prompting user's attention, in the form of a Promotion-type includes:
}


DAILY DEAL ALERT! " " Today only! Get your ebook copy of Find You in the Dark for only \$2.99,

"A wickedly smart thriller that manages to be both chilling and wry. The page-turning plot $\ldots$ is thickened by a great cast of characters and Nathan Ripley's fantastic eye for detail and dialogue. Just when you think you've got a grasp on it, the story twists to new and darker places."

- AMY STUART, bestselling author of Still Mine

Read more: https://goo.gl/jJKdfZ

Behavioral engagement was exhibited through various forms of sharing, endorsing and learning, primarily through user-user and user-administrator interactions in comments. Sharing was demonstrated in user's willingness to “exchange experience, ideas or just interesting content...driven by the motivation to find resources (Dessart, Veloutsou, \& Morgan-Thomas, 2015)". Already indicative in users using affordances like "share", "comment" and "like", sharing was also found in user's comments, An example includes:

User: I went and got the book right after you were on the social. Have started to read it done halfway awesome your cousin from St Thomas Dan's wife. Wish we could see you are you doing a book sign in London?

Learning was also exhibited in user's comments, as well in administrator's replies to comments. Learning consists of consumers "[seeking] help, ideas, resources and information from the company or other consumers (Dessart, Veloutsou, \& Morgan-Thomas, 2015)". Examples include:

User: I had to switch over to goodreads becauae the 50bookpledge site would not work properly on my phone Administrator: Hi User, we're really sorry to hear this! Please send us a DM or email to savvyreader(at)harpercollins(dot)com to let us know what isn't working for you and we'll help fix the issue.

$* * *$

User: Can't seem to get logged into my account

Administrator: Hi User! Please try clearing your cache and cookies on your web browser and then attempt signing in again. Let us know if you are still experiencing difficulties! 
Endorsing exists when users "actively recommend specific brands, products/services, organizations and/or ways of using products or brands (Dessart, Veloutsou, \& Morgan-Thomas, 2015)", and was most relevant primarily in comments recommending particular book titles to other users, or approving of already-read titles posted by the publisher in product-type posts. Examples include:

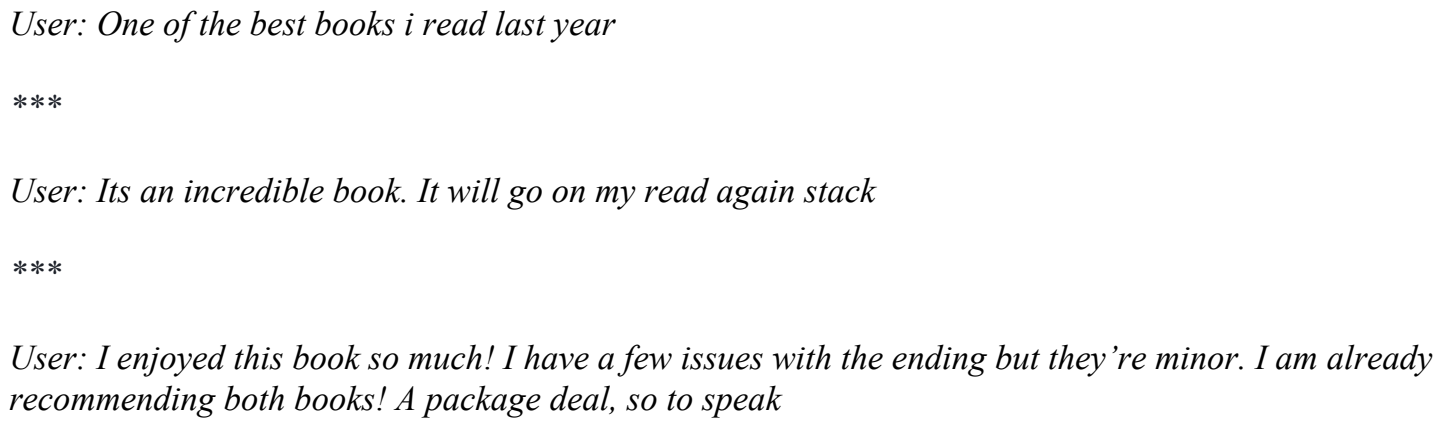

These engagement dimensions were also prevalent differently among the three publishers and the two platforms:

PRHC Facebook. Most comments made by users favoured behavioral engagement, followed by affective engagement. More comments demonstrated more cognitive engagement than with the other two publishers, with users typically returning to the platform to interact with other users - primarily debating the content of a book, for example:

User 1: Just finished reading the book theif. Interesting who the narrator is.

User 2: Who? You mean the audible narrator?

User 1: No I mean the story is told by an interesting point of view

User 3: I thought it was death? The narrator I mean [...]

User 1: It was to me, the angel of death.

The administrator on Facebook had little to no interaction with users in this 18 week period.

PRHC Instagram. This platform had four times more comments than on Facebook, and administrator response was much higher. Again, users interact primarily with affective and 
behavioral forms of engagement, with a more equal distribution between the two. Administrator comments reinforced positive forms of affective and behavioral engagement made by the users, making comments like:

User: Reading it right now

Administrator: Looking forward to hearing your thoughts! Happy reading!

$* * *$

User: I need this. The cover is beautiful and $i$ haven't read any of her poetry yet but i think i'd absolutely love it [emo]

Administrator: She's a fantastic poet and this book is a great collection to start with. Let us know what you think and happy reading [emo] [emo]

HC Facebook. 3081 comments were made over the total 18 week period, excelling as the highest number of comments on any platform by any of the three publishing brands. HC followers also demonstrated a higher degree of cognitive engagement than the other two publishers. The administrator fostered attention and absorption from the users by replying to almost every user comment, personalizing these replies for users, tagging them in these replies and asking questions to continue to prompt and continue attention and absorption from users. Examples of these types of interactions include:

User 1: Seems like all the Big Books are named "The Girl Next Door to the Woman in the Cabin on the Train with the Window"

Administrator: You forgot "...in the Woods" [emo]

User 2: With a dragon tattoo.

User 3: Who fell into the water...

User 4: From off the Train ....

Administrator: Haha, [tag User 2,3,4] I'd read that!

User: Picked it up yesterday. Can't wait to read it.

Administrator: Hope you love it. Let us know! We always like to hear. 
User: My goal is 50 books this year.

Administrator: Great! Good luck. What did you get to last year?

Additionally, Harper Collins users demonstrated an equal distribution of affective and behavioral engagement in their comments.

HC Instagram. Harper Collins users made a total of 1086 comments over this 18 week period, with the majority demonstrating more affective forms of engagement than behavioral engagement.

SS Facebook. With the highest number of posts total, Simon \& Schuster followers exhibited more affective engagement than behavioral. Administrator responses reinforced behavioral forms of engagement, particularly in the learning dimension, by primarily answering user questions and queries. Responses did not vary in structure and format and remained the same for all users, for example:

User: how often can you enter

Administrator: Only one entry per person but you can always make your family and friends enter for you.

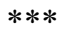

User 1: I can't submit to enter--check your site.

Administrator: Hi User 1, were you trying to enter using a mobile device? Sometimes the tool we use has issues with mobile devices. If you have access to a computer we suggest trying to enter again using that. Apologies for the inconvenience and frustration.

User 2: I don't see a submit button anywhere...?

Administrator: Hi User 2, Were you trying to enter using a mobile device? Sometimes the tool we use has issues with mobile devices. If you have access to a computer we suggest trying to enter again using that. Apologies for the inconvenience and frustration.

SS Instagram. Users here also engaged in the highest number of comments between all publishers (with 1338 overall). Affective forms of engagement were majorly displayed by users than behavioral. 
Table 5.1: Engagement Dimensions Evident in Facebook Comments for Each Publisher.

\begin{tabular}{|c|c|c|c|c|c|c|c|}
\hline & \multicolumn{2}{|c|}{ AFFECTIVE } & \multicolumn{2}{|c|}{ COGNITIVE } & \multicolumn{3}{|c|}{ BEHAVIORAL } \\
\hline & ENTHUSIASM & ENJOYMENT & ATTENTION & ABSORPTION & ENDORSING & LEARNING & SHARING \\
\hline PRHC & $\begin{array}{l}\text { "Love to read...I } \\
\text { love reading to my } \\
\text { grandkids" } \\
\text { "What a beautiful } \\
\text { cover! I have been } \\
\text { wanting to read the } \\
\text { first book. Would } \\
\text { be great to win it!" }\end{array}$ & $\begin{array}{l}\text { "Must read. I love } \\
\text { Ms Robinson's } \\
\text { work. So looking } \\
\text { forward to this } \\
\text { book!" } \\
\text { "yes! Those pics } \\
\text { show how books } \\
\text { make me feel and } \\
\text { how they get the } \\
\text { gray matter going!" }\end{array}$ & & $\begin{array}{l}\text { "Just finished } \\
\text { reading The Book } \\
\text { Thief. Interesting } \\
\text { who the narrator } \\
\text { is." } \\
\text { "Who? You mean } \\
\text { the Audible } \\
\text { narrator?" } \\
\text { "No. I mean the } \\
\text { story is told by an } \\
\text { interesting point of } \\
\text { view. - I thought it } \\
\text { was death? the } \\
\text { narrator, I mean. I } \\
\text { have read this a } \\
\text { few times, I am } \\
\text { thinking of hearing } \\
\text { it next. such an } \\
\text { intense experience } \\
\text { though. I have to } \\
\text { be in the right } \\
\text { mood. one of the } \\
\text { best books ever I } \\
\text { think." } \\
\text { "It was, to me, the } \\
\text { angel of death." }\end{array}$ & $\begin{array}{l}\text { "I read 'American } \\
\text { War'. Recommend } \\
\text { it." } \\
\text { "I recommend } \\
\text { Broken Angels, by } \\
\text { Gemma Liviero. It } \\
\text { gives new voices to } \\
\text { lesser-known facts } \\
\text { and goings on of } \\
\text { Nazi ruled } \\
\text { Germany and the } \\
\text { camps during } \\
\text { WWII in a } \\
\text { movingly written } \\
\text { fiction novel." }\end{array}$ & $\begin{array}{l}\text { "Is it fiction or } \\
\text { non-fiction?" } \\
\text { "it is fiction set in } \\
\text { the future" } \\
\text { is the artist?" } \\
\text { "Enotered. Thank } \\
\text { you. Yes, who is } \\
\text { the artist of the } \\
\text { cover?" }\end{array}$ & $\begin{array}{l}\text { "[tag] I can't go but maybe you can!" } \\
\text { make it a habit to read with my grandson. } \\
\text { Read out loud if I am reading one of my } \\
\text { books. At present I've got my nose in Al } \\
\text { Gore's latest. Yes out loud and Michael } \\
\text { asks me questions!" } \\
\text { "[tag] Perfect for our girl's book club!" }\end{array}$ \\
\hline HC & $\begin{array}{l}\text { "This is } \\
\text { awesome!" } \\
\text { "This looks so } \\
\text { interesting" } \\
\text { "Would love this } \\
\text { book" } \\
\text { "Want to read !!" }\end{array}$ & $\begin{array}{l}\text { "It's my newest } \\
\text { Staff Pick at } \\
\text { Chapters Windsor. } \\
\text { Great read!" } \\
\text { "I'm starting it } \\
\text { today.. we are in } \\
\text { the path of a } \\
\text { Nor'easter so will } \\
\text { be nice and cozy } \\
\text { by the fireplace } \\
\text { and a hot drink } \\
\text { reading it } \otimes \text { Can't } \\
\text { wait!" }\end{array}$ & & $\begin{array}{l}\text { "does listening } \\
\text { to books count } \\
\text { as } \\
\text { reading...cause } \\
\text { i listen to about } \\
\text { a book a week } \\
\text { driving around } \\
\text { for my job..." } \\
\text { "I would say it } \\
\text { definitely } \\
\text { counts!!" } \\
\text { "Have you read } \\
\text { How to Stop } \\
\text { Time yet?" } \\
\text { "I read How to } \\
\text { Stop Time } \\
\text { when it first } \\
\text { came out. I } \\
\text { loved it so } \\
\text { much that I } \\
\text { purchased The } \\
\text { Humans. } \\
\text { Which Matt } \\
\text { Haig book do } \\
\text { you } \\
\text { recommend I } \\
\text { read next?"” } \\
\text { "Oh geeez! All of } \\
\text { them. Iloved The } \\
\text { Radleys, but his } \\
\text { nonfiction Reasons } \\
\text { to Stay Alive is } \\
\text { great too" }\end{array}$ & $\begin{array}{l}\text { "the next time } \\
\text { you need a new } \\
\text { book to read, } \\
\text { this one might } \\
\text { be worth } \\
\text { checking out!" } \\
\text { "My \#CEO100 } \\
\text { pick! If you're } \\
\text { in Barrie, stop } \\
\text { by Chapters, } \\
\text { I'll gush about } \\
\text { how great this } \\
\text { book is and sell } \\
\text { you a copy! } \\
\text { Also our Teen } \\
\text { Staff Pick of } \\
\text { the Month!" }\end{array}$ & $\begin{array}{l}\text { "Get it at } \\
\text { Costco... } \\
\text { cheapest price } \\
\text { around" } \\
\text { " } 40 \% \text { off at Indigo! } \\
\text { Canadian company } \\
\text { too" } \\
\text { "Is this a different } \\
\text { edition? I think } \\
\text { this is already } \\
\text { available in } \\
\text { Canada?" }\end{array}$ & $\begin{array}{l}\text { "I had to switch over to goodreads becauae } \\
\text { the } 50 \text { bookpledge site would not work } \\
\text { properly on my phone" } \\
\text { "I always have at least two books on the go } \\
\text { all the time. Always carry one in my purse. } \\
\text { Love mysteries and disaster books" } \\
\text { "[tag] this one!" }\end{array}$ \\
\hline SS & $\begin{array}{l}\text { "Ordered your new } \\
\text { book today can't } \\
\text { wait" } \\
\text { "Can't wait to read } \\
\text { this one" } \\
\text { "Looking forward } \\
\text { to reading this, } \\
\text { thanks for the } \\
\text { opportunity" }\end{array}$ & $\begin{array}{l}\text { "I always knew } \\
\text { this was true } \\
\text { [emo]" } \\
\text { "Thanks for the } \\
\text { giveaway and the } \\
\text { oppourtunity to } \\
\text { win. Most of these } \\
\text { books are on my } \\
\text { tbr list." }\end{array}$ & & & $\begin{array}{l}\text { "Just finnished it } \\
\text { last night. Not easy } \\
\text { to read at times but } \\
\text { so informative" } \\
\text { "Was so moved by } \\
\text { this that i made a } \\
\text { donation to als" }\end{array}$ & $\begin{array}{l}\text { "Wish we could } \\
\text { see you, are you } \\
\text { doing a book sign } \\
\text { in London?" } \\
\text { "How often can } \\
\text { you enter?" }\end{array}$ & $\begin{array}{l}\text { "Ordered, being shipped and patiently (well } \\
\text { sort of) waiting for the doorbell to ring to } \\
\text { let me know its arrived. I purposely didn't } \\
\text { start a new book after i finished my last one } \\
\text { on Saturday night so I can dive into this } \\
\text { one. Im hoping to have it read by March } 28 \\
\text { when i see her in toronto" } \\
\text { "I bought the book and it is helpful. I did } \\
\text { the clothes first and it was the easiest. But i } \\
\text { don't think she wrote it for seniors" }\end{array}$ \\
\hline
\end{tabular}


Table 5.2: Engagement Dimensions Evident in Instagram Comments for Each Publisher.

\begin{tabular}{|c|c|c|c|c|c|c|c|}
\hline & \multicolumn{2}{|c|}{ AFFECTIVE } & \multicolumn{2}{|c|}{ COGNITIVE } & \multicolumn{3}{|c|}{ BEHAVIORAL } \\
\hline & ENTHUSIASM & ENJOYMENT & ATTENTION & ABSORPTION & ENDORSING & LEARNING & SHARING \\
\hline PRHC & $\begin{array}{l}\text { "I neeeeeed this! } \\
\text { The cover is } \\
\text { beautiful and I } \\
\text { haven't read any of } \\
\text { her poetry yet but I } \\
\text { think I'd absolutely } \\
\text { love it } 8 \text { " } \\
\text { "!! this is now top } \\
\text { of my tbr pile" }\end{array}$ & $\begin{array}{l}\text { "Just finished } \\
\text { reading this } \\
\text { gorgeous work last } \\
\text { night. What a } \\
\text { beautiful } \\
\text { meditation on life } \\
\text { and love and death } \\
\text { and } \\
\text { you [tag]" } \\
\text { "Thank you! } \\
\text { Reading it right } \\
\text { now and loving it!" }\end{array}$ & & & $\begin{array}{l}\text { "[tag] you'd like } \\
\text { this!" } \\
\text { "Even if I've read } \\
\text { all of the articles } \\
\text { possible about the } \\
\text { bachelor and what } \\
\text { it's like in the } \\
\text { house and read all } \\
\text { of the contestants } \\
\text { books, will I } \\
\text { STILL be } \\
\text { surprised?" }\end{array}$ & $\begin{array}{l}\text { "Did you guys } \\
\text { already choose a } \\
\text { winner for } \\
\text { @ harleypasternak } \\
\text { book?" } \\
\text { "Hi there - it looks } \\
\text { like the contest } \\
\text { closed two days } \\
\text { ago and } \\
\text { @penguincanada } \\
\text { will be reaching } \\
\text { out to the winner } \\
\text { directly. Stay tuned } \\
\text { for news from } \\
\text { them. Good luck!" }\end{array}$ & $\begin{array}{l}\text { "[tag] mama can I has please?" } \\
\text { "[tag] can we get this and have a book } \\
\text { club?" }\end{array}$ \\
\hline HC & $\begin{array}{l}\text { "Omg! This cover } \\
\text { is so freakin } \\
\text { gorgeous that I } \\
\text { can't even handle } \\
\text { [emo] [emo] [emo] } \\
\text { [emo] [emo]" } \\
\text { "Im dying to read } \\
\text { this" }\end{array}$ & $\begin{array}{l}\text { "Itd be an absolute } \\
\text { pleasure to meet } \\
\text { the author. Email } \\
\text { sent. Waiting for a } \\
\text { reply. Fingers } \\
\text { crossed." } \\
\text { "Love this contest! } \\
\text { So many amazing } \\
\text { books to vote for! } \\
\text { It was hard to } \\
\text { pick!" }\end{array}$ & & $\begin{array}{l}\text { "So true and thank } \\
\text { goodness we have } \\
\text { them! ! finished a } \\
\text { book this morning } \\
\text { and already have } \\
\text { my next picked out } \\
\text { [emo]" } \\
\text { "Oh which one?" } \\
\text { "Im just starting an } \\
\text { arc of jessica } \\
\text { knoll's the } \\
\text { favourite sister" } \\
\text { "Wow! Thats so } \\
\text { great to hear! } \\
\text { Which is your local } \\
\text { bookstore? [tag]" }\end{array}$ & $\begin{array}{l}\text { "One of the best } \\
\text { books i read last } \\
\text { year" } \\
\text { "Its an incredible } \\
\text { book. It will go on } \\
\text { my read again } \\
\text { stack" } \\
\text { "I enjoyed this } \\
\text { book so much! I } \\
\text { have a few issues } \\
\text { with the ending but } \\
\text { they're minor. I am } \\
\text { already } \\
\text { recommending } \\
\text { both books! A } \\
\text { package deal, so to } \\
\text { speak" }\end{array}$ & $\begin{array}{l}\text { "What exactly is } \\
\text { the book pledge? } \\
\text { And if we sign up } \\
\text { do y'all email us a } \\
\text { bunch or what? I } \\
\text { already have my } \\
\text { goal set on } \\
\text { goodreads" } \\
\text { "If you like Harry } \\
\text { Potter and Avatar } \\
\text { the Last Airbender, } \\
\text { then you'd love } \\
\text { The Legends of } \\
\text { Eve!" }\end{array}$ & $\begin{array}{l}\text { "Maybe a new read for us? [tag]" } \\
\text { "[tag] for your book club?" } \\
\text { "[tag] so you're going to buy it for me for } \\
\text { my birthday?" }\end{array}$ \\
\hline SS & $\begin{array}{l}\text { "So excited for this } \\
\text { one! Can't wait to } \\
\text { read this!" } \\
\text { "This book sounds } \\
\text { incredible! The } \\
\text { perfect haunting } \\
\text { birthday present to } \\
\text { myself!"' } \\
\text { "oooohhhhh yes } \\
\text { please!" }\end{array}$ & $\begin{array}{l}\text { "I loved this book } \\
\text { so much!" } \\
\text { "A gorgeous } \\
\text { read!" } \\
\text { "Thank you for } \\
\text { bringing tima kurdi } \\
\text { to burlington last } \\
\text { evening. We are } \\
\text { beyond honored to } \\
\text { have heart her } \\
\text { story [emo]" }\end{array}$ & & & $\begin{array}{l}\text { "I've heard good } \\
\text { things about this } \\
\text { \#novel. It's on my } \\
\text { wish list } \\
\text { [emo][emo]" } \\
\text { "It was an amazing } \\
\text { read, and i would } \\
\text { highly recammend } \\
\text { this book. After } \\
\text { seeing the book } \\
\text { trailer, i hope there } \\
\text { will be a movie } \\
\text { adaptation in the } \\
\text { future! [emo] } \\
\text { [emo]" }\end{array}$ & $\begin{array}{l}\text { "Can't find link in } \\
\text { bio" } \\
\text { "Do you know if } \\
\text { there is a second } \\
\text { book for this? } \\
\text { Because the ending } \\
\text { says they are } \\
\text { taking another field } \\
\text { trip?" }\end{array}$ & $\begin{array}{l}\text { "[tag] based on the title alone, i think you'll } \\
\text { enjoy! [emo]" } \\
\text { "[tag] look at that book" } \\
\text { "[tag] have you looked at this one?" }\end{array}$ \\
\hline
\end{tabular}




\section{DISCUSSION}

The findings of this paper helped support previous research in the relationship between brand personas and online brand communities, according to Papadatos (2006) and Shen \& Bissell (2013). All three publishers published posts of a similar nature and thus, all three publishers maintained a clear brand identity and role for consumers, maintaining a recognizable archetype (Papadatos, 2006). This was done by primarily advertising and marketing product-type posts the most, especially new books, accentuating the publisher's brand roles as entertainment providers towards consumers, constantly showering consumers with new products (books) they could get their hands on. As Shen and Bissell (2013) previously indicated, promotion-type posts were generally avoided, and if posted, contained the least amount of engagement from users, especially when a price tag was involved, as seen in SS, where promotion-type posts had the least amount of engagement overall. Even with posts promising book giveaways and prompting users to engage with these promotion-type posts, more meaningful engagement was found in product and dialogue-type posts. The publishers, thus, maintained a brand identity of being a "friend" towards "bookworm" consumers, in accordance with past brand-persona marketing research, where it is suggested that brands "masquerade to be something else (Shen and Bissell, 2013, p. 648)", and therefore, it makes sense that publishers advise and gift consumers books to feed and suit their reading needs rather than directly sharing promoting information. This also correlates with engagement, with consumers supporting this "masquerade" persona, and not interacting with more direct, promotion-related posts. Additionally, users prioritized behavioral engagement on these publisher's platforms, with comments mostly endorsing publisher's books, advising books to other users through reviews, as well as sharing their own personal reading experiences. The ways in which publishers used the platforms and how users responded to post content is beneficial for the book publishing brand; however, product-type posts may not be as effective for other brands and companies who are not as reliant on product distribution as book publishers are.

All three publishers used Facebook and Instagram simuairly when it came to advertising

and marketing their products and upcoming related events - however, the platforms were found 
to be used for different functions. All three publishers posted content daily, sometimes once or twice daily or between 2-3 times a week. SS made the highest number of posts in 18 weeks, however, this did not lead to a correlation in engagement, with SS having lower engagement with users, compared to PRHC and HC, who posted slightly less but had higher engagement through affordance use. Additionally, there was no variation between the number of posts on Facebook and the number of posts on Instagram; however, each of the publishing houses favoured one platform over the other - PRHC favoured Instagram, HC and SS both favoured Facebook. It was also seen that administrators were more present on their respective favoured platform, replying more to comments and encouraging more engagement between and with users. Favouring platforms could be due to differences in each publisher's preferred consumer-base - HC and SS could be catering to older consumers by favouring Facebook engagement whereas PRHC is attempting to cater towards younger consumers with Instagram (Brandtzaeg, 2011).

When it came to customizing and catering content between the two platforms, post content remained very similar - book summaries, giveaways and event-type post content contained word-by-word language. However, post language was customized to suit each platform's affordances, and accomodate the ways in which the platform functioned, therefore determining the ways in how consumers used each platform and reacted to posts. Additionally, differences in post content between platforms also confirmed previous studies indicating Facebook as a platform for information delivery and exchange (Shen \& Bissell, 2013) and Instagram's role as a personal branding tool (Dessart, Veloutsou, \& Morgan-Thomas, 2015). Posts made by publishers cater to each platform's affordances, asking users to "like" on Facebook, and "double tap" on Instagram. Additionally, notions of community are emphasized on Facebook ("if you want to be part of our community of...readers") whereas the self is emphasized on Instagram ("if you're making reading a priority...we want YOU to join us in making this the best bookish year yet"), adapting to previous studies labelling Instagram as more of a personal branding tool (Dessart, Veloutsou, \& Morgan-Thomas, 2015) and thus allowing users to build on their ideals of self-expression (Kaplan \& Haenlein, 2010). Links were also more common on Facebook, encouraging inter-connectivity and sharing between users, whereas 
on Instagram, hashtags and emojis were used more commonly by the administrator and users alike, allowing users to preserve and maintain self-presentation and self-branding, as previously suggested by Kaplan \& Haenlein (2010). The purpose of sharing information on Facebook goes beyond post content made by publishers, and also exhibits itself in user comments. Facebook users made longer and more personal comments that went beyond the posted content publishers made. Users were also more willing to interact with other users on Facebook, compared to Instagram. Facebook users were more willing to share personal stories, engage with other users (other than the administrator), supporting purposes of community.

Different types of engagement dimensions, suggested by Dessart, Veloutsou, \& Morgan-Thomas (2015) were exemplified in this research. Affective and behavioral types of engagement were most relevant among all three publisher brands, favouring dimensions of enthusiasm, enjoyment, endorsing and sharing, contributing to the publisher's brand identities and role towards their consumers. Cognitive engagement was least evident in user comments on Facebook and Instagram and was more evident in post content made by the administrator. In the cases in which cognitive engagement was exemplified in comments (most obviously in HC platforms) was only in the condition that the administrator also made replies to users, tagging them, and thus prompting attention. In the case of the three publishing brands, capitalization, questions and other forms of persuasive language was used in administrator posts and comment replies that prompted user attention and continued absorption into the online brand community. Additionally, users that made comments on more than one post can be labelled as displaying cognitive engagement, as they return to each respective platform to continue to engage with the community. Newer types of affordances recently introduced to Facebook and Instagram, like stories, emoticon reactions, and product tagging that were not studied or observed in this paper could also lead towards confirming previous studies and perhaps even generate new insights into online engagement.

As Shen and Bissell (2013) previously suggested, dialogue-type posts are still not completely “embraced by...brands/companies (p.647)", as is seen in the results of this paper. Alongside promotion-type posts, dialogue-type posts were least used by the publishers, with the exception of HC. HC's postings contained more questions posed for users to answer through 
affordance use, making their posts most engaged with out of all three publishers on both platforms. HC attempted to curate comments that were more personalized to specific users and the comments they posted. HC's administrator not only customized replies, but also attempted to continue and prompt engagement with other users, effectively growing engagement. Though all three publishing brands had similar ways of advertising and marketing their books on both platforms, the publishers differed in the ways that they responded to users and therefore, consequently promoting or detering engagement with both the brand and other users.

According to the findings of this paper, conceptualizations of brand persona storytelling are evident in how brands are using different social media affordances. As post content remains the same between platforms, administrators utilize platform affordances and their post/response language to support user's expectations when using a specific platform (Kaplan \& Haenlein, 2010). Specific aspects of a brand's personality are reflected in the ways that the brand uses an affordance to engage its consumers. The three publishers emphasized aspects of reading and "book worm" behavior as a part of their brand personality. This relatability to consumers was reflected in the way publishers used affordances. Publishers asked consumers to use an affordance if consumers accepted and/or approved of a specific aspect of the publisher's personality that they were presenting on social media. Publishers, through their post and affordance use, acknowledged that their consumers were using SNS platforms, and following their brand to reflect facets of the individual consumer's personality. Dialogue posts, especially those that highlighted this relatability to consumer's personalities showed to be the most engaging. Continuing to pursue this type of posts and brand persona is beneficial for publishers they are already successful in generating engagement with users on both platforms, as evidenced here. In order to continue to implement effective and meaningful engagement, however, dialogue-type posts and comments need to be emphasized in publisher's current social media strategies. Like in the case of $\mathrm{HC}$, administrators should be more active in interacting with user's comments and encourage engagement in their replies. This may help to increase engagement in affordance use, and help publisher's posts be shared and seen by more users on each platform. 


\section{CONTRIBUTIONS}

A thorough content analysis was conducted, giving detailed insight into the ways in which consumers are interacting with one another and with brands on different social media platforms. Having this understanding might allow brands to better customize and cater their content and brand personas on different social media platforms. In this paper, a brand's persona was characterized by observing how the brand's administrator interacted with its consumers online. Affordance use was linked to successful engagement between both the brand and its community of users, and the interactions within the brand community. Thus, the findings of this paper may help to shape future research in social media marketing and engagement, allowing brands to better develop effective social media strategies that potentially lead to improved engagement with and between consumers.

This paper also provides additional insight into the purposes and use of Facebook and Instagram platforms for a specific market of users. This insight into publisher's consumer-base's interactions online might allow publishers to continue to shape social media content to better fit

their user's expectations of the publisher's page on a particular platform. Specific post-types can be implemented into publisher's social media to improve engagement between and with consumers, based on the success or failure of post-types found in this paper.

Engagement dimensions, as suggested by Dessart, Veloutsou, \& Morgan-Thomas (2015) were evidenced in user's online comments on both platforms. Additionally, the results of this paper go beyond the book publishing market itself and can be fit to cater to any brand's social media strategy. By identifying the several types of engagement found in comments, brands may be able to better implement cognitive-type engagement dimensions in their online interactions with users, or determine which engagement dimensions are lacking. Additionally, these interactions can help brands build a more defined and structured brand persona online that users want to communicate with.

Finally, these findings observed how book publishers are currently integrating brand persona strategies successfully in their post content. The ways in which publishers (particularly 
HC) are currently posting and interacting with users is ideal for effective engagement, aligned with their brand personality and the expectations consumers have for both the brand and the SNS platform they are using. Curating content to fit a platform's affordances has shown to be an effective means of maintaining and improving engagement. Additionally, by acknowledging the differences between the two social media platforms and the users that inhibit them, it might allow a brand to effectively integrate these ideals into their social media to improve engagement, based on these three examples. 


\section{FUTURE RESEARCH}

There were several limitations to this study that can be implemented into future research efforts in the topics of brand personas and social media affordances. Firstly, this study was based on the observations of one individual and on the analysis of a specific brand and consumer-base. Implementing a different methodology and repeating this study on other brands may help validate these results and generalize them in a larger context. Also, the classification of post-types and engagement dimensions can be interpreted differently by others if this study were to be repeated. Future studies might be able to classify and analyze affordances differently than this study suggests in order to confirm the presence of engagement. Secondly, this study concentrated on only two social media platforms and did not take into account other and newer social media platforms that have become popularized in recent years. Additionally, this study only looks at affordances already studied in previous research ("like", "comment", "share") and does not look at affordances introduced into Facebook and Instagram in recent years (stories, reactions, product tagging, etc.). Thus, future studies may opt to analyze different social media platforms popularized by younger consumers (like Snapchat) in order to establish whether engagement dimensions are also present in their respective contexts and available affordances. Furthermore, studying the effectiveness of new affordances not observed here, may also help determine their effectiveness to engage with younger consumers. New affordances may also play a more critical or central role in brand storytelling which was not observed in this study. Affordances that change and are altered on a daily basis - for example, the use of stories on Instagram, the use of reactions on Facebook, that were not measured here) can be more indicative of the emotional responses consumers have to posts and content, and the purposes of social media affordances in relation to user behavior. 


\section{REFERENCES}

Anderson, P. (2017). BookNet Canada: Digital Revenue Up in 2016, Ebook Sales Down. Retrieved April 12, 2018, from https://publishingperspectives.com/2017/06/booknet-canada-2016-state-of-digital-publishi $\mathrm{ng} /$

America, J. 0. (2012). Transmedia Storytelling, Fan Culture and the Future of Marketing. Retrieved March 01, 2018, from http://knowledge.wharton.upenn.edu/article/transmedia-storytelling-fan-culture-and-the-fu ture-of-marketing/

Berthon, P.R. Pitt, L.F., Plangger, K., Shapiro, D. (2007). Marketing meets web 2.0, social media, and creative consumers: Implications for international marketing strategy. Business Horizons, 55, 261-271. Doi: 10.1016/j.bushor.2012.01.007.

BookNet Canada. (n.d.) Print book sales declined in 2017. Retrieved April 12, 2018, from https://www.booknetcanada.ca/press-room/2018/1/15/print-book-sales-declined-in-2017

Brandtzaeg, P.B. (2011). Social networking sites: Their users and social implications - a longitudinal study. Journal of Computer-Mediated Communication, 17:4, 467-488. doi: 10.1111/j.1083.6101.2012.01580.x. Retrieved from: http://onlinelibrary.wiley.com/doi/10.1111/j.1083-6101.2012.01580.x/full

Brodie, Roderick J., Ana Ilic, Biljana Juric, and Linda D. Hollebeek (2013). Consumer engagement in a virtual brand community: An exploratory analysis. Journal of Business Research. 66, 1, 105-14.

Cabiddu, F., Carlo, M. D., \& Piccoli, G. (2014). Social media affordances: Enabling customer engagement. Annals of Tourism Research,48, 175-192. doi:10.1016/j.annals.2014.06.003

Carmody, B. (2016). Transmedia Marketing Is the Future of Brand Storytelling. Retrieved March 01, 2018, from https://www.inc.com/bill-carmody/transmedia-marketing-is-the-future-of-brand-storytellin g.html

Cronin, J. (2015). Teach students to communicate a brand story with transmedia storytelling. Journal of Research in Interactive Marketing, 10:2, 86-101. https://doi.org/10.1108/JRIM-01-2015-0004.

DeFina, A. (2016). How To Tell Your Brand Story On Social Media. Retrieved April 12, 2018, from 
https://www.forbes.com/sites/theyec/2016/02/22/how-to-tell-your-brand-story-on-social-m edia/\#1d34cb867a3a

Dessart, Laurence \& Veloutsou, Cleopatra \& Morgan-Thomas, Anna. (2015). Consumer engagement in online brand communities: A social media perspective. Journal of Product \& Brand Management. 24. 28-42. 10.1108/JPBM-06-2014-0635.

DeVault, G. (2018). How Market Research Is Like Anthropology. Retrieved April 12, 2018, from

https://www.thebalance.com/investigate-social-media-like-an-anthropologist-2297153

Forbes, T. (2016). Social's Impact On Transmedia. Retrieved March 01, 2018, from https://www.mediapost.com/publications/article/284781/socials-impact-on-transmedia.htm 1

Fournier, S. (1998). Consumers and Their Brands: Developing Relationship Theory in Consumer Research. Journal of Consumer Research,24(4), 343-353. doi:10.1086/209515

Gambetti, R., \& Graffigna, G. (2010). Consumer-Brand Engagement. Wiley Encyclopedia of Management,1-3. doi:10.1002/9781118785317.weom090054

Gottschall, J. (2012). The storytelling animal: How stories make us human. Boston: Mariner Books.

Gürel, E., \& Tığlı, Ö. (2014). New World Created by Social Media: Transmedia Storytelling. Journal of Media Critiques, 1(1), 35-65. doi:10.17349/jmc114102

Hanna, R., Rohm, A. \& Crittenden, V.L. (2011). We're all connected: The power of the social media ecosystem. Business Horizons, 54, 265-273. Doi: 10.1016/j.bushor.2011.01.007. Retrieved from: https://wolfman.one/wp-content/uploads/2013/05/BH_HannaRohmCrittenden2011.pdf

Harper Collins (2018). Company Profile. Retrieved from: https://www.harpercollins.com/worldwide/about-us/company-profile/

Henning-Thurau, T., Malthouse, E.C.. Friege, C., Gensler, S., Lobschat, L., Rangaswamy, A. and Skiera, B. (2004). Electronic word-of-mouth via consumer-opinion platforms: What motivates consumers to articulate themselves on the internet. Journal of Interactive Marketing, 18(1), p. 38-52.

Herskovitz, S., \& Crystal, M. (2010). The essential brand persona: Storytelling and branding. Journal of Business Strategy,31(3), 21-28. doi:10.1108/02756661011036673 
Hochman, N., \& Manovich, L. (2013). Zooming into an Instagram City: Reading the local through social media. First Monday, 18(7). doi:10.5210/fm.v18i7.4711

Hollebeek, L. D., Glynn, M. S., \& Brodie, R. J. (2014). Consumer Brand Engagement in Social Media: Conceptualization, Scale Development and Validation. Journal of Interactive Marketing,28(2), 149-165. doi:10.1016/j.intmar.2013.12.002

Hsieh, H.F and Shannon, S.E. (2005). Three approaches to qualitative content analysis. Qualitative Health Research. 15(9). pp. 1277-1288. Doi: https://doi.org/10.1177/1049732305276687

Hussein, D., Alaa, G., \& Hamad, A. (2011). Towards Usage-Centered Design Patterns for Social Networking Systems. Communications in Computer and Information Science Future Information Technology,80-89. doi:10.1007/978-3-642-22309-9_10

IBIS. (2018) Book Publishing - Canada Market Research Report. Retrieved from: https://www.ibisworld.ca/industry-trends/market-research-reports/information/book-publis hing.html

Kaplan, A. M., \& Haenlein, M. (2010). Users of the world, unite! The challenges and opportunities of Social Media. Business Horizons, 53(1), 59-68. doi:10.1016/j.bushor.2009.09.003

Kozinets, R. (1998),"On Netnography: Initial Reflections on Consumer Research Investigations of Cyberculture", in NA - Advances in Consumer Research Volume 25, eds. Joseph W. Alba \& J. Wesley Hutchinson, Provo, UT : Association for Consumer Research, Pages: 366-371.

Lin, K., \& Lu, H. (2011). Why people use social networking sites: An empirical study integrating network externalities and motivation theory. Computers in Human Behavior,27(3), 1152-1161. doi:10.1016/j.chb.2010.12.009

Livingstone, S. (2008). Taking risky opportunities in youthful content creation: teenagers use of social networking sites for intimacy, privacy and self-expression. New Media \& Society, 10(3), 393-411. doi:10.1177/1461444808089415

Losowsky, A. (2013). DRM Lawsuit Filed by Independent Bookstores Against Amazon, 'Big Six' Publishers. Retrieved from:

https://www.huffingtonpost.ca/entry/drm-lawsuit-independent-bookstores-amazon_n_272 7519

Mangold, W. G., \& Faulds, D. J. (2009). Social media: The new hybrid element of the promotion mix. Business Horizons, 52(4), 357-365. doi:10.1016/j.bushor.2009.03.002 
Mar, R. A. (2004). The neuropsychology of narrative: Story comprehension, story production and their interrelation. Neuropsychologia,42(10), 1414-1434.

doi:10.1016/j.neuropsychologia.2003.12.016

Moreau, E. (2018). Everyone's Using This App Called Instagram... What Is It? Retrieved April 12, 2018, from https://www.lifewire.com/what-is-instagram-3486316

Nations, D. (2018). What Is Facebook? Here's What You Should Know. Retrieved April 12, 2018, from https://www.lifewire.com/what-is-facebook-3486391

Nawotka, E. (2017). Book Sales Reps: More Important Than Ever. Retrieved April 12, 2018, from

https://www.publishersweekly.com/pw/by-topic/industry-news/bookselling/article/72703book-sales-reps-more-important-than-ever.html

Nelson, O. (1989). Storytelling: Language Experience for Meaning Making. Reading Teacher,42(6), 386-390. doi:EJ383725

O'Riordan, S., Feller, J., Nagle, \& Tadhg. (2012). Exploring the affordances of social networking sites: An analysis of three networks. 20th European Conference on Information Systems. Retrieved from https://cora.ucc.ie/bitstream/handle/10468/5168/4408_EXPLORING_THE_AFFORDAN CES_OF_SOCIAL_NETWORK_SITES-_AN_ANALYSIS_OF.pdf?sequence=1\&isAllo wed $=\mathrm{y}$.

Papadatos, C. (2006). The art of storytelling: How loyalty marketers can build emotional connections to their brands. Journal of Consumer Marketing, 23(7), 382-384. doi:10.1108/07363760610712902

PRHC (2018). About Penguin Random House Canada. Retrieved from: https://www.penguinrandomhouse.ca/about

PRH (2018). Penguin Random House: Our Story. Retrieved from: https://www.penguinrandomhouse.com/about-us/our-story/

Publishers Weekly (2016). Publishing Leaders 2016: Simon \& Schuster. Retrieved from: https://www.publishersweekly.com/pw/by-topic/industry-news/publisher-news/article/713 36-global-publishing-leaders-2016-simon-schuster.html

Randall, W. L., Prior, S. M., \& Skarborn, M. (2006). How listeners shape what tellers tell. Journal of Aging Studies, 20(4), 381-396. doi:10.1016/j.jaging.2005.11.005 
Scolari, C. (2009). Transmedia Storytelling: Implicit Consumers, Narrative Worlds, and Branding in Contemporary Media Production. International Journal of Communication,3. Retrieved from http://ijoc.org/index.php/ijoc/article/view/477

Shen \& Bissell (2013) Social Media, Social Me: A Content Analysis of Beauty Companies' Use of Facebook in Marketing and Branding, Journal of Promotion Management, 19:5, 629-651, DOI: 10.1080/10496491.2013.829160

Thibeault, J. (2013). Is Transmedia Storytelling the New Digital Marketing? Retrieved April 12,2018 , from http://jasonthibeault.com/2013/10/17/is-transmedia-storytelling-the-new-digital-marketing /

Weilenmann, A., Hillman, T., \& Jungselius, B. (2013). Instagram at the museum. Proceedings of the SIGCHI Conference on Human Factors in Computing Systems - CHI 13. doi:10.1145/2470654.2466243

Whiting, A., \& Williams, D. (2013). Why people use social media: a uses and gratifications approach. Qualitative Market Research: An International Journal, 16(4), 362-369. doi:10.1108/qmr-06-2013-0041

Woodside, A. G., Sood, S., \& Miller, K. E. (2008). When consumers and brands talk: Storytelling theory and research in psychology and marketing. Psychology and Marketing,25(2), 97-145. doi:10.1002/mar.20203

Zhao, Y., Liu, J., Tang, J., \& Zhu, Q. (2013). Conceptualizing perceived affordances in social media interaction design. Aslib Proceedings, 65(3), 289-303.

doi:10.1108/00012531311330656 